OPEN ACCESS

Citation: Enrico Foietta (2021) An Unexpected Journey. The French Expedition of Charles Fossey at Hatra (Iraq). Asia Anteriore Antica. Journal of Ancient Near Eastern Cultures 3: 153-172. doi: 10.36253/asiana-1132

Copyright: ( 2021 Enrico Foietta. This is an open access, peer-reviewed article published by Firenze University Press (http://www.fupress.com/asiana) and distributed under the terms of the Creative Commons Attribution License, which permits unrestricted use, distribution, and reproduction in any medium, provided the original author and source are credited.

Data Availability Statement: All relevant data are within the paper and its Supporting Information files.

Competing Interests: The Author(s) declare(s) no conflict of interest.

\section{An Unexpected Journey - The French Expedition of Charles Fossey at Hatra (Iraq)}

\author{
ENRICO FOIETTA \\ Università di Torino \\ efoietta@unito.it
}

\begin{abstract}
This paper deals with the overlooked French Expedition of the famous architect Charles Fossey at the end of the 19th century at Hatra (Northern Iraq) using information of unpublished documents from the Archive Nationale de France. The collected data shed new light on the understanding of Small Shrine 2, one of the fourteen small shrines built inside the districts of the city.
\end{abstract}

Keywords. Hatra, French Expedition, Fossey, Small Shrine 2, Parthian period.

\section{INTRODUCTION}

The archaeological site of Hatra, al-Hadr in Arabic, is located at about $80 \mathrm{kms}$ from Mosul (Iraq) in northern Mesopotamia. During the $2^{\text {nd }}$ and $3^{\text {rd }}$ century AD, the centre became the capital of an important buffer state placed between the Roman and Parthian Empires (Hauser 2000; Venco Ricciardi 2008; Hauser 2009; Foietta 2018: 141-150). The settlement, founded during the Post-Assyrian period (end of $5^{\text {th }}-4^{\text {th }}$ century BC) ${ }^{1}$, flourished during the first two centuries of the Common Era. The city was delimited by a double pseudo-circular curtain wall defining a large built area of about 300 ha. The complex urban layout was framed by a tortuous street network, demarcating districts, where dwelling areas, small shrines, and monumental funerary buildings are recognizable. In the centre of the city is the Temenos, built in ashlar blocks, where the most important temples were located. ${ }^{2}$

Numerous archaeological, historical, and epigraphic questions have been answered, thanks to different archaeological expeditions and explora-

\footnotetext{
${ }^{1}$ For a brief account of the first phases of the city: Kaizer 2013: 59-60.

${ }^{2}$ For a general overview about the site: Venco Ricciardi 2000; Foietta 2018. For the fortifications: Gawlikowski 1994; Foietta 2015; 2016. For the recent researches and studies on different topics about the city and related references: Sommer 2003; 2005; Dirven 2013a; Dorna Metzger 2016; Venco Ricciardi, Parapetti 2016; Foietta 2018; Marcato 2018; Moriggi, Bucci 2019.
} 
tions carried out during the $19^{\text {th }}$ and $20^{\text {th }}$ centuries, from the first preliminary expeditions by English explorers, to the contemporary archaeological excavations of the Iraqi, Polish, and Italian archaeologists. ${ }^{3}$

This paper focuses on the overlooked French Expedition to Hatra, directed by Architect Charles Fossey at the end of the $19^{\text {th }}$ century, which was the first archaeological excavation at the site, furnishing new suggestions about Small Shrine 2, built in the city layout.

\section{BEFORE THE FRENCH ARCHAEOLOGICAL EXPEDITION: THE ENGLISH AND FRENCH EXPLORERS AT HATRA}

In May1836, John Ross, an English surgeon working in Baghdad, left the capital with the purpose of reaching Hatra. It was not a well-planned undertaking, for several reasons. It would be detailed for the first time a few years later, along with a subsequent trip, in a long article published on the Geographical Journal in 1839 (Ross 1839: 443-470). During that first visit, which lasted only a few hours, the small group was forced to flee from the site due to an attack from the Shammar, a nomadic local tribe that controlled the area ruled by the Pasha of Mosul (Ross 1839: 443).

Their second attempt, the following year, was better organised by involving local chiefs of the Shammar tribes to prevent reprisals from their groups as well as attacks from the other big local tribe, the belligerent Aneizah. This allowed Ross to visit Hatra safely for several hours on 15 May 1837 (Ross 1839: 460, 463). On that occasion, Ross drew the first simplified plan of the site, reporting for the first time the Sasanian circumvallation wall (Hauser, Tucker 2009; Hauser 2013), the main pseudo-circular wall, the inner wadi, at the time registered_as a channel, several funerary buildings in the western part of the city, mounds for the residential areas in the eastern part of the city, and the central Temenos, containing some buildings (Ross 1839: 467-470) (Fig. 1). The paper wrongly reported a diameter of approximately 2 miles, together with other incorrect data about the main curtain wall, such as the ones regarding the regular distance between the defensive towers and the homogeneity of the building technique for the fortifications (Ross 1839: 467). Nevertheless, the information reported have been of great importance and usefulness to scholars throughout the years. Ross also identified the two funerary buildings $\mathrm{N}$ and $\mathrm{E}$ outside the curtain wall, in front of the city gates (Ross 1839: 467-468). Such ruins were still clearly visible during the German Expedition, directed by W. Andrae, and were accurately documented in his fundamental volume published in 1912. Ross also mistakenly reported a strict division of the city in a western, residential part and an eastern part assigned to the necropolis, which was rectified by scholars in later studies (See the plan of Ross 1839: 470).

Ross' analysis focused on the Temenos central complex, particularly on the Great Iwans and Twin Iwans, suggesting they served as a palace or a temple, the latter function being confirmed by the systematic Iraqi investigations and cleaning of the site undertaken in the $1950 \mathrm{~s}^{4}$ (Fig.2). The English author provided the general measures of the ruins, reporting that there were less blocks and debris in the eastern part than in the western one, which featured important constructions, such as the Great Iwans and the Twin Iwans (Ross 1839: 468-470).

Ross describes the iwans from south to north. He started by analysing the small south iwan and preceded to the small north iwan, as they are called, from the Great Northern Iwan. He indicates the approximate measures of the rooms and describes the architectural decoration, focusing on the 'flat' masques on the blocks and the sculpted voussoirs in situ (Ross 1839: 468-469)5. The architectural decoration was described at length by explorers and archaeologists of the time; the historical photographs by G. Bell and W. Andrae of the voussoirs and decorated ashlars from the Great and Twin Iwans are well known and famous to all the scientific community, along with

\footnotetext{
${ }^{3}$ For the history of research and relative bibliography: Venco Ricciardi 2000; Foietta 2018: 7-24. A new Italian Expedition began the works at the site in 2020 (University of Padova and ISMEO). For a general account: https://www.ismeo.eu/portfolio_page/hatra/. Last view: 10/06/2021

${ }^{4}$ For an account of the Iraqi expeditions and related references: Foietta 2018: 14-18.

${ }^{5}$ For the architectural decoration in the temples of the Temenos: Venco Ricciardi 2015.
} 
their interesting drawings. ${ }^{6}$ Strangely enough, Ross does not report the presence of statues on the ground at the site, although they had been mentioned by members of the local tribes.

In the same year of Ross' trip, the site was briefly visited by H.B. Lynch, English Lieutenant, whose expedition had the purpose of drawing a trigonometric map from the Armenian mountains to Baghdad. In his short report however, the author did not mention the ruins of Hatra, even if he places the site on the map (Lynch 1839).

During the spring of 1840, a group composed by E.L. Mitford, A.H. Layard, Mr Rassám, and W. Ainsworth, together with an expert local guide and a convoy sent by the Pasha of Mosul, visited North Mesopotamia. A first report of this expedition was published by W. Ainsworth in 1841 on the Journal of Royal Geographical Society and republished using the same data in Travels and Researches in Asia Minor, Mesopotamia, Chaldea and Armenia II (Ainsworth 1841). It provided a more detailed description of the ruins at the site and rectified Ross' division between a necropolis and dwelling area. Also, the tortuous inner wadi was correctly attributed and no longer considered as a channel. A long part of the paper is devoted to the study of the ruins of the central Temenos, with the publication of some drawings by A.H. Layard of decorated blocks with masques from the Iwans and a sketch of the elaborated lintel placed between the Square Temple and the South Iwan (Fig. 3). A façade of one of the funerary stone buildings of the city, which is difficult to identify, is also represented. ${ }^{7}$ Also, quoted here for the first time are the Zengid inscriptions engraved on the Great Iwans mentioning the names of the Atabeg of Mosul (Ainsworth 1841: 14; Andrae 1912: 108; Aggoula 1991: X; Parapetti, Venco Ricciardi 2013: 220).

Layard's report was published only several years later (1891) in Transactions: Vol. VII. New Series. His description of the city mostly coincides with the accounts given by Ainsworth and Ross, while also focusing on water resources at the site (Layard 1891: 64-65). The graphic documentation drawn on tracing paper by Layard is extremely interesting. His plan of the Temenos identifies many of the important architectural complexes, which would be uncovered only in the later works by Andrae and Iraqi archaeologists (Layard 1891) (Figs 4-5). In 1897, Ch. Jacquerel, Ingenieur des Ponts et Chaussées at Mosul, published a short paper in French after a visit to the site, under the title 'Les Ruines de Hatra' on the Revue Archéologique. Jacquerel reported some significant information about the urban layout and the fortification, identifying on the field the most important elements of the curtainwalls and the line of Sasanian circumvallation. ${ }^{8}$ Jacquerel also accurately described the central ruins of the Temenos, publishing a plan of the Great Iwans complex and of the Twin Iwans, the latter represented as a single room due to the rubble found inside, just as in Ross' previous drawings. The French scholar also sketched some drawings of the voussoirs, door frames, and lintels, including the one situated between the Square Temple (Fig. 6) and the Great South Iwan, as well as the inscription H246.

\section{THE FRENCH EXPEDITION OF CHARLES FOSSEY - A FORGOTTEN EXPEDITION}

In 1898, after submitting a first request to Constantinople for permission to excavate at Çatal Tepe in Turkey, the French architect Fossey, was authorized to start working at al-Hadr (Hatra), in Mosul district. Fossey's expedition proposal came at a particular time, that is when France was falling behind other European nations, especially Germany, in the field of excavations and archaeological research in the Ottoman Empire territories (Chevalier 2002: 63-112). Fossey submitted his request, after the failed attempt of creating a first 'Mission de Costantinople' -suggested by A. Joubin and J. Cambon, consul at Constantinople (Chevalier 2002: 83-89) - and when the 'École française d'Athene', directed by T. Homolle had just advanced a similar proposal (Chevalier 2002: 89-90). In the summer of 1898, after receiving fundings (15.000 francs) from the French Ministry, this new French centre was finally created

\footnotetext{
${ }^{6}$ Andrae 1912, 107-165, Taf. VII-XXIII. The photographs regarding Hatra preserved at the Gertrude Bell's Archive are 79: R00148, Q227-236. The pictures R0049-68 represent Ottoman troops placed close to Hatra and tribesmen. http://gertrudebell.ncl.ac.uk/ search_photos_results.php?search_photos=Hatra\&start=0, last view: 10/06/2021.

${ }^{7}$ For the funerary buildings: Dorna Metzger 1998; 2000.

${ }^{8}$ Jacquerel 1897: 344. On the Sasanian wall: Hauser 2013 with extended references.

9 Jacquerel 1897: 351. This inscriptions, as others from Hatra, mentions the Temenos as Esagil (Aggoula 1991: 123; Beyer 1998: 77).
} 
under the direction of the Byzantinist Charles Diehls. Fossey had previously studied at the School of Athens for three years, starting from 1894, and had spent one year at the 'Institut Français du Caire', building contacts that turned out to be useful to obtain the permission documents from the Sacred Door (Nougayrol 1946: 25).

Having already spent part of the money at Mosul for his two-month stay without the excavation permit (irade), Fossey decided to reach Hatra immediately after its release at the beginning of January. The field report and the story of his travel are preserved in a folder of unpublished documents stored at the Archives Nationales de France - Paris (F17/2963). ${ }^{10}$ Without having viewed such documents, B. Aggoula mentioned Fossey's expedition in his book on Hatra inscriptions, suggesting that the French archeologist did not even visit the site directly.

In Fossey's folder the information reported in a letter he sent to the French Ministry dated 30 April 1899 (Fig. 7) is of great relevance (Appendix 1), as are the enclosed photographs, which remain the first pictures ever taken at the site (Figs 8-14). ${ }^{11}$ The letter, which Fossey wrote to obtain new funds for a second mission that would focus mainly on the Temenos area, reports two field trenches. However, Fossey's expedition did not last long, as the attacks of local tribes forced Fossey and his team to seek refuge inside the Temenos for several days.

The exact location of the French trenches became known thanks to the data published in 1912 in W. Andrae's volume, where the areas explored more or less ten years earlier are mentioned (Fig. 15) (Andrae 1912: 61, 70). A first trench (a) reaches across a landfill located west of Small Shrines 3 and 4, in the western part of the city. The area is placed precisely inside urban area AU16 and in squares 111 or 114 of Andrae's grid (Foietta 2018: 310-313; Andrae 1912: 61).

The second trench (b) was dug in correspondence with the Small Shrine 2, named Gebäude T by Andrae, and with a partially excavated house added westward (Andrae 1912: 70). This is where the French expedition focused its efforts; the same area that would later be explored in depth by an Iraqi expedition in the 1950s (Safar 1952: 37-52). The archive folder does not include any plans of the explored rooms, nor a more detailed documentation about the trenches and works.

The French Expedition also explored and surveyed the Temenos area, probably without carrying out any soundings. The tent camp for the workers and for Fossey's staff was certainly pitched in this area where, according to one of the pictures, the most remarkable pieces from this expedition were identified: a relief depicting an attendant or a god, a dog on a pedestal, and a standard, now preserved at the Istanbul Archaeological Museum (Fig. 13). ${ }^{12}$

\section{THE DISCOVERY FINDINGS}

Fossey's letter does not mention any object from the landfill area (a) (Fig. 15); here a large quantity of pottery sherds and organic layers was probably discovered, as successively reported by W. Andrae for similar areas or for another area excavated by J. Ibrahim north of the Temenos (Urban area 10 - AU10) (Ibrahim 1997-1998; Foietta 2018: 209).

From the area of Small Shrine 2 and the house built westward comes a Hatran inscription, identified with H28, engraved on two blocks $(56 \times 23 \mathrm{~cm}$ e $57 \times 32 \mathrm{~cm}$ ) and probably belonging to the base of a statue (Aggoula 1991: 22-23; Beyer 1998: 35) (Fig. 11). Interestingly, the inscription reports the name of Sanatruq II (AD 200241), the last king of Hatra, and his wife and son, the last one with the title prggrb', usually translated as 'crownprince' (Gnoli 2002: 79). It is probably a dedication from the statue of Sanatruq II's wife, btsmy' (Marcato 2018: 45), 'Daughter of Samya', placed inside or in front of Small Shrine 2, as customary for several small shrines in the city, or in the nearby west dwelling area. The French expedition left the inscription at the site due to the weight of the blocks and it was later found and published by the Iraqi Archaeological Expedition that cleared the area near the shrine (Safar 1953: 15).

\footnotetext{
${ }^{10}$ I visited the Archives Nationales de France in 2017; I would like to thank this institution for allowing me to publish these documents and the photographic documentation.

11 The photographs have been already published in Foietta 2018: 32; while the text of the letter is unpublished.

${ }^{12}$ See the next paragraph for the description.
} 
A statuette of an enthroned woman on a base with an inscription fragment, a bust of a naked male, a small statue of a warrior god with a sceptre (Fig. 12), and another fragment were also collected in the area of Small Shrine 2.

On the basis of the iconography, the statuette of the woman (h. $29 \mathrm{~cm}$ ), whose head is not preserved, could be most probably be interpreted as a goddess on a throne, with a dog sculpted to her right and another crouching animal to her left (Fig. 16). She wears a tunic with sleeves at the elbow and a long garment with an elaborate drapery. A long girdle tied at the waist softly falls on her the knees. Her neck and breasts are adorned with two interesting necklaces: a short torques with small pendants and a long necklace with loop-in-loop chain with a round central medallion. She holds a palm branch, or a feather, in her left hand, and a small oblong object (stylus or distaff) in the other hand. The analysis and study of the sculpture has been proposed by L. Dirven, finding convincing comparisons inside and outside Hatra (Dirven 2013b). According to preliminary works by H.J.W. Drijvers and H. Ingholt, the goddess should depict Atargatis, but an identification with Allat or another local goddess of the Hatrean pantheon is far more likely, as suggested by Dirven (Dirven 2013b: 148-153). The statue is now preserved at the Archaeological Museum of Istanbul (inv. no. 3831), following the partition law of antiquities, which established that $2 / 3$ of the findings belonged to the Ottoman Empire, while the remaining 1/3 could be brought to the foreign state (Chevalier 2002: 497-500). As stated by Dirven, the museum acquired the statue, a few years after its discovery (1908).

Given the image preserved in Fossey's folder (Fig. 13), the famous relief with dog $(55 \mathrm{x} 45 \mathrm{~cm})$, attendant/god and standard (samya) was probably discovered inside the Temenos area, possibly close to the Great Iwans. ${ }^{13}$ The object, now preserved at the Archaeological Museum of Istanbul (inv. no. 3829) (Homès-Fredericq 1963: 56), was also studied in detail by Dirven in the same paper examining the enthroned goddess (Dirven 2013b: 151-152) (Fig. 17). On the right of the relief, a dog is engraved in left profile on a plinth. A keeper or a god with a spear (?) in the right hand and a sword on the left one is represented on the left part of the relief. Between the two described elements, an elaborated standard (samya) is sculpted. The dog on the pedestal is usually interpreted as the representation of a statue of the god Nergal, considering also the title Nergal klb', attested several times in Hatran inscriptions, and translated differently as 'Nergal the dog', 'Nergal of the dog' or 'Nergal keeper of the dog' (Dirven 2013b: 151, footnote 43).

The naked bust of a man, as indicated by Fossey, was probably brought to France and its precise location at the moment is unknown, while the small headless deity, probably in marmar (gypse), was taken to Istanbul as per the partition law (Fig. 12).

\section{SHEDDING A NEW LIGHT FROM AN ARCHIVE RESEARCH. SMALL SHRINE 2: COMBINING DATA FROM THE FRENCH AND IRAQI EXCAVATIONS}

An Iraqi Archaeological Expedition, directed by F. Safar, excavated the Small Shrine 2 and the western house built close to it during the 1950s (Safar 1952: 37-52) (Fig. 18a, b). The shrine is located south of the Temenos along the so-called south circumvallation, where the Small Shrines 1 and 8 were also built. ${ }^{14}$ The shrine is similar in shape to other religious complexes situated in the dwelling area, with a wide antecella $(16.2$ × $5.9 \mathrm{~m})$ and a narrow square cella (5.1 x 5.0 m), T-shaped shrine (Jakubiak 2014: 72-74) (Figs 19-20). Two square basements flanked the entrance were located, and were probably the plinths for the statues or the guardian lions, as in the case of Small Shrine 1.

Along the walls of the cella there are no basements, which in other cases sustained statues of gods, kings or lords, priests, and nobles. Two rooms were built on both sides of the cella during a second phase of the shrine.

\footnotetext{
${ }^{13}$ The relief could have also been discovered in Small Shrine 2 and brought only subsequently to the French camp in the Temenos area. However, this suggestion is questionable, because other objects that were found there were photographed near Small Shrine 2 and not by the Great Iwans.

${ }^{14}$ On the circumvallation: Foietta 2018: 203.
} 
These rooms were probably part of the domestic complex built to the west. According to Safar, the domestic area should be interpreted as part of the palace of Sanatruq II, the last king of Hatra, even if he did not provide further data to support this idea (Safar 1951).

Several goddesses statues have been found inside the shrine:

- a goddess on a round bas-relief resting on a carved crescent moon (Safar, Mustafa 1974: no. 193) (Fig. 21);

- a fragmentary female statue. A tunic covering the lower part of her body drapes over her shoulder, a necklace with a medallion decorates her naked breasts and a partially broken crescent moon extends from her shoulders. A diadem on her head (Safar, Mustafa 1974: no. 194) (Fig. 22);

- a relief with three standing goddesses wearing long tunics. The goddess on the right shows a halo and a moon crescent on her upper back (Safar, Mustafa 1974: no. 192) (Fig. 23).

A burner was also discovered in the antecella (h. $90 \mathrm{~cm}$, w. $35 \mathrm{~cm}, \mathrm{t} .30 \mathrm{~cm})$. On its main face is carved a bearded male figure, who has been identified with Nergal for the similarity of the iconographic features with the famous 'Cerberus relief' from Small Shrine 1, or better a Zaqiqu, given the presence of the inscription H13 on it, mentioning this particular god (Fig. 24). ${ }^{15}$

According to the archaeologists who excavated the shrine, Small Shrine 2 was dedicated to Atargatis for the iconography of the female goddess (Safar, Mustafa 1974: 204) (Fig. 22), while according to K. Jakubiak, it was dedicated possibly to Nanaya, Atargatis, or to another local goddess (Jakubiak 2013: 93-94; Jakubiak 2014: 72-74).

The findings uncovered by the French Expedition, whose location is impossible to attest precisely, must be added to the statues found by the Iraqi Archaeological Expedition. The presence of the enthroned goddess (Fig. 16) confirms the hypothesis that the entire shrine could be devoted to an important goddess, who was worshipped alongside other 'secondary' deities, as was a common practice in smaller shrines at Hatra. The recovery of the small warrior deity statue with a sceptre must be considered in this sense. The small statue could be identified with a local god, quite similar to others recovered in other minor shrines. The naked male bust could be identified with a fragment of a Herakles/Nergal, although only a direct survey of the statue would settle the issue. ${ }^{16}$ The left arm seems to be in fact at a right angle as to hold something, perhaps a cup or the apples of the Hesperides, similarly to other statues of Heracles/Nergal at the site (Fig. 12).

The inscription (H28) mentioning the mother of Sanatruq II's son, 'bad Samya, could come both from the area of the small shrine, given the numerous dedications of statues discovered inside the small shrines, or from the domestic complex, reinforcing Safar's suggestion that this was the palace of Sanatruq II, although the dimensions and features of the rooms do not seem to support this assumption. It is interesting in any case that the statue of Sanatruq II's wife and mother of the crown-prince was not discovered during the French and Iraqi Excavations. For this reason, it is possible to suggest that the statue was most likely located in an area of the house that had not been excavated yet, or that the buildings (shrine and house) were sacked during the final siege of Hatra (AD $240 / 1$ ), or (more plausible) that the 'queen' statue was incomplete and still had to be placed on its basement. Perhaps the dramatic historical events of the last years of Hatra prevent its placement on the basement?

The study of the finds discovered inside Small Shrine 2, or in its proximity, by cross-checking both published and unpublished information from different archaeological expeditions, allows 'fresh' interpretations that are based on the existing photographs, notes and archive documents, without the need of new field research. This method is economically sustainable and is indeed relevant because it could be further improved and rapidly extended to other religious contexts of the city. In fact, the Iraqi State Board of Antiquities and Heritage archive contains a considerable amount of unpublished information concerning the Small Shrines excavated in the Fifties, which, alongside data preserved in other archives of archaeological expeditions, would represent a fundamental source for the future to better understand such religious buildings, where kings, aristocrats and priests made their offerings to the deities of the local pantheon.

\footnotetext{
15 Safar, Mustafa 1974: 191; Foietta 2019: 201. On H13, see Aggoula 1991, 11-14.

${ }^{16}$ For the identification as a male bust, see Appendix 1.
} 


\section{BIBLIOGRAPHY}

Aggoula B. 1991, Inventaire des inscriptions hatréennes, (Bibliothèque Archéologique et Historique139), Paris, Librairie Orientaliste Paul Geuthner.

Ainsworth W. 1841, Notes of an Excursion to Kal'ah Sherkat, the U'r of the Persians, and to the Ruins of Al Hadhr, the Hutra of the Chaldees, and Hatra of the Romans, Journal of the Royal Geographic Society 11: 1-20.

Andrae W. 1912, Hatra nach Aufnahmen von Mitgliedern der Assur-Expedition der deutschen Orient-Gesellschaft. II. Teil. Einzelbeschreibung der Ruinen, (Wissenschaftliche Veröffentlichung der deutschen Orient-Gesellschaft 21), Leipzig, Hinrichs.

Beyer K. 1998, Die aramäischen Inschriften aus Assur, Hatra und dem übrigen Ostmesopotamien: datiert 44 v. Chr. bis 238 n. Chr., Göttingen, Vandenhoeck \& Ruprecht.

Bruno J. 2016, Preliminary Report in the "Small Finds" from the Italian Excavations at Hatra, ARAM 28: 277-302.

Chevalier N. 2002, La recherche archéologique française au Moyen-Orient 1842-1947, Paris, Éditions Recherche sur les Civilisations.

Dirven, L. 2013a (ed.), Hatra: Politics, Culture and Religion between Parthia and Rome (Oriens et Occidens 21), Stuttgart, Franz Steiner Verlag.

Dirven, L. 2013b. A Goddess with Dogs from Hatra, in A. Peruzzetto, F. Dorna Metzger, L. Dirven (eds), Animals, Gods and Men from East to West. Papers in archaeology and history in honour of Roberta Venco Ricciardi, (BAR International Series 2516), Oxford, BAR Publishing: 147-160.

Dorna Metzger F. 1998, Funerary Buildings at Hatra, Electrum 2: 45-53.

Dorna Metzger F. 2000, Hatra: gli edifici funerari, Topoi 10: 197-215.

Dorna Metzger F. 2016, The North Street at Hatr: A Multifunctional Area, ARAM 28, 303-326.

Foietta E. 2018, Hatra. Il territorio e l'urbanistica, Oxford, Archaeopress.

Gawlikowski M. 1994, Fortress Hatra. New Evidences on Rampart and their History, Mesopotamia 29: 147-184.

Gnoli T. 2002, 'Paṣgribä' at Hatra and Edessa, in A. Panaino, G. Panaino (eds), Ideologies as Intercultural Phenomena. Proceedings of the Third Annual Symposium of the Assyrian and Babylonian Intellectual Heritage Project Held in Chicago, USA, October 27-31, 2000, Milano, Università di Bologna e IsIAO: 79-87.

Hauser S. 2000, Ecological Limits and Political Frontiers: The 'Kingdom of the Arabs' in the Eastern Jazirah in the Arsacid Period, in L. Milano, S. de Martino, G.B. Lanfranchi (eds) Landscapes. Territories, Frontiers and Horizons in the Ancient Near East. Papers Presented to the XLIV Rencontre Assyriologique Internationale. Venezia 7-11 July 1997, II: Geography and cultural landscapes, Padova, Sargon: 187-201.

Hauser S. 2009, Hatra et Assur. Centres religieux et commerciaux, Dossiers d'Archéologie 334: 72-77.

Hauser S., Tucker D. 2009, The Final Onslaught. The Sasanian Siege of Hatra, Zeitschrift für Orient-Archäologie 2: 106-139.

Homès-Fredericq D. 1960, La vie à Hatra à la lumière de la sculpture, Sumer 16: 39-44.

Ibrahim J. 1997-1998, Hatra: The Excavation of the Cubic Building at Hatra in 1989, Sumer 49: 219-230.

Jacquerel Ch. 1897, Les Ruines de Hatra, Revue Archéologique 31: 343-352.

Jakubiak K. 2013, A Note on the Inscriptions and Architectural Decorations from the Small Temples, in L. Dirven (ed.) Hatra: politics, culture and religion between Parthia and Rome, (Oriens et Occidens 21), Stuttgart, Franz Steiner Verlag: 91-106.

Jakubiak K. 2014, Sacral Landscape in Hatra, Warsaw, Instytut Archeologii.

Kaizer T. 2013, Questions and problems concerning the sudden appearance of material culture of Hatra in the first centuries CE, in L. Dirven (ed.) Hatra: politics, culture and religion between Parthia and Rome, (Oriens et Occidens 21), Stuttgart, Franz Steiner Verlag: 57-71.

Layard H. 1891, Notes on the Ruins of the Palace of Al Hather (Hadhr). Communicated by the Rt.

Hon Sir. Henry Layard, G.C.B. (then Mr. Layard), in 1846, Transactions of the Royal Institute of the British Architects 7: 63-68.

Lynch H.B. 1839, Note on a part of the river Tigris, between Baghdàd and Sàmarrah, The Journal of the Royal Geographical Society of London 9: 471-476. 
Marcato E. 2018, Personal Names in the Aramaic Inscriptions of Hatra, Venezia, Edizioni Ca' Foscari.

Moriggi M., Bucci I. 2019, Aramaic Graffiti from Hatra. A Study Based on the Archive of the Missione Archeologica Italiana, (Culture and History of the Ancient Near East 99), Leiden - Boston, Brill.

Nougayrol J. 1946, Charles Fossey (1869-1946), Ecole pratique des hautes études, Section des sciences religieuses. Annuaire 1947-1948: 25-29.

Parapetti R., Venco Ricciardi R. 2013, Hatra, documenti e note sul Santuario del Sole, in A. Invernizzi (ed.),

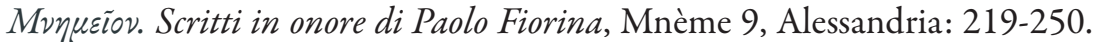

Ross J. 1839, Notes on Two Journeys from Baghdad to the Ruins of Al Hadr, in Mesopotamia, in 1836 and 1837, Journal of the Royal Geographic Society of London 9: 443-470.

Safar, F. 1952, Hatra and the First Season of Excavation, Sumer 8: 3-16.

Safar, F.1953, Inscriptions of Hatra, Sumer 9: 7-20.

Safar F., Muștafa M.A. 1974, Hatra: The City of Sun God, Baghdad, General Directorate of Antiquities.

Al-Salihi W. 1978, Hatra, London, Iraqi Cultural Centre Gallery.

Sommer M. 2003, Hatra: Geschicte und Kultur einer Karawanerstadt im römisch-parthischen Mesopotamien, Mainz, Philip von Zabern.

Sommer M. 2005, Roms orientalische Steppengrenze. Palmyra - Edessa - Dura-Europos - Hatra, (Oriens et Occidens 9), Stuttgart, Franz Steiner Verlag.

Venco Ricciardi R. 2000, Hatra: Presentazione del Sito, Topoi 10: 87-110.

Venco Ricciardi R. 2008, Hatra e il suo territorio: un problema storico, La Parola del passato. Rivista di studi antichi 63: 139-168.

Venco Ricciardi R. 2015, Decorazione architettonica figurata del grande Temenos di Hatra, Mesopotamia 50: 209242.

Venco Ricciardi R., Parapetti R. 2016, Hatra, the Sanctuary of the Sun God in Christian and Medieval Times, ARAM 26, 393-428.

\section{APPENDIX 1}

Charles Fossey's Letter to the Minister of Education (Ministre de l'Instruction et des Beaux Arts)

Monsieur le Ministre,

Vous m'avez fait l'honneur de m'accorder en 1898 les premiers fonds nécessaire pour entreprendre des fouilles à Tchatal Tépé et, au printemps dernier, sur un avis de l'Ambassade, je partais pour Constantinople. Le Gouvernement turc déclarait ne pas s'opposer aux fouilles et attendre seulement le consentement du propriétaire du terrain pour un délivrer l'autorisation nécessaire. J'espérais obtenir en consentement contre une indemnité raisonnable, mais je me heurtai à des prétentions inacceptables. Féherir - Pacha voulait que l'Ambassadeur le fut nommer Montessarif d'un sanjah indépendant; il se serait contenté d'une promesse mais appuyée d'un dépôt de quarante mille francs. J'avais perdu trois mois à négocier avec lui et fait une première brèche avec crédits qui n'étaient alloués : je voulais une compensation. J'échouai encore dans une demande que je fis pour fouiller à Laktché Gömel dans la même région que Tchatál tépé et c'est au mois de Septembre seulement que j’obtins du Ministre de la Liste civile la promesse ferme d'une autorisation pour El-Hadra. Je me trouvais ainsi amené par le force des circonstances à entreprendre des travaux beaucoup plus considérables que ceux pour lesquels j'avais demandé et obtenu des crédits : je devais en outre faire jusqu'à Mossoul un long et couteaux voyage. Mais que je crus que l'essentiel était de faire quelque chose et je partis sans hésiter. Malgré les promesses du Ministre, j'attendis encore à Mossoul deux mois pendant lesquels mes fonds allèrent sans cesse diminuant. D'autant plus que, pour utiliser et séjour forcé sur les bords du Tigres, j'avais entrepris d'aller à Bavian estamper les inscriptions de Sennachérib. Quand enfin l'iradé arriva, quand j'eus réglé les dernières formalités avec les autorités locales, je m'aperçus qu'il ne me restait guère que l'argent nécessaire a mon retour. Je pouvais d'autant moins y songer que devant fouiller sur un terrain appartenant 
au Sultan, j'avais obtenu de pacha de la liste civile à Mossoul des conditionnes tout a fait exceptionnelles. Il m'accordait conformément à l'ancienne loi turque, la seule qu'il connaît sans doute, le tiers des objets trouvés et je savais que la sortie des antiquités par Bassorah n’offrait aucune difficulté. J'adressai donc l'Académie des Inscriptions une demande des subsides et j'organisai mon départ pour El-Hुaḍra. Je partis de Mossoul le 7 Janvier avec une cinquantaine d'ouvriers et des provisions pour deux mois, car je ne devais rien trouver sur place, mon champ de fouille se trouvait en plain désert, à trois journées de Mossoul et à deux journées du village le plus rapproché. Arrivé le 9 Janvier, je ne pus commencer les travaux que le 16, à cause d'une bande de Bédouines qui nous tint assiégés sur le ruine du palais jusqu'à l'arrivée des secours envoyés par le Vali. J'attaquai alors un de nombreux monticules qui entourent l'enceinte du palais comme le montrent le photographies, 1., 2. et 3., et j'eus le bonheur de trouver des les premiers jours une inscriptions en caractère araméennes (photo n. 4), une statuette féminine avec une inscription araméenne sur la base, un torse de homme (photo n. 6) et deux autres fragments de statuettes. J'ouvris plusieurs autres tranchées, mais je ne puis pas les pousser assez loin, spécialement dans un endroit que je suppose avoir été le sanctuaire particulier du palais : les murés sont conservés dans toute leur hauteur mais le voûte très centré a, en s'effondrant, entassé sur le sol plus de trois mètres de pierres. La somme que j'avais eu pouvoir avancer en attendant la réponse de l'Académie des Inscriptions, était épuisée e comme je l'appris en rentrant à Paris, des préoccupations plus graves avaient empêché Monsieur Collignon de transmettre une demande à l'Académie.

Je dus donc interrompre les travaux et suivre au retour. L'inscription araméenne restait sur le chantier, faute de ressources pour la transporter i parmi les autres objets. Je choisi le torse que je rapportai en France et que je tiens à la disposition du Musé du Louvre.

Je n'ai guère pas fait qu'un sondage à El-Hुaḍra, mais il m’a paré justifier pleinement mes espérances et démontrer l'intérêt que présenterais des fouilles sinon complètes - le champ est immense du moins prolongées. Il faudrait dégager les pièces principales du palais et tout d'abord celle où je place le temple, reconnaître une certain nombre d'édifices disséminés dans l'enceinte de la ville et fouiller une certaine de maisons comme celle qui m'a fourni les objets mentionnés plus haut.

Les résultats seraient certainement importants pour l'épigraphie sémitique et pour l'histoire de l'art.

Je vous demanderai dons Monsieur le Ministre.

$1^{\circ}$ de vouloir bien de me faire rembourser une somme de deux mille cinq cents franc que j'ai dépensais en plus de crédits qui m’était alloué.

$2^{\circ}$ de m'accorder le crédit nécessaire pour entreprendre et mener à bien des fouilles sérieuses. Je le voudrais suffisant pour être assuré que les travaux ne seront pas une seconde fois interrompus. Chaque interruption, chaque voyage représentent une perte d'argent considérable. Mon désir serait de rester sur le terrain, au tant au moins dans la contrée, jusqu'au l'achèvement des fouilles. Si elles doivent être suspendues pendant quelques mois d'été. Je voudrais, au bien de rentrer en France, explorer le pays et notamment la montagne de Sindjar.

Notre connaissance de villages du Mossul est si imparfaite qu'on ne peut pas [...] avec parti de données géographiques contenues dans les inscriptions assyriennes.

Mes dépenses, en fouillant avec une cinquantaine d'ouvriers, s'élèvent à environ cent franc par jour. Il me faudrait donc trente mille francs pour travailler dix mois, plus dix mille francs pour voyage d'aller et retour, achat de matière, transport des antiquités, etc, soit en tout quarante mille francs.

Veuillez agréer, Monsieur le Ministre, l'assurance de mon profond respect. 


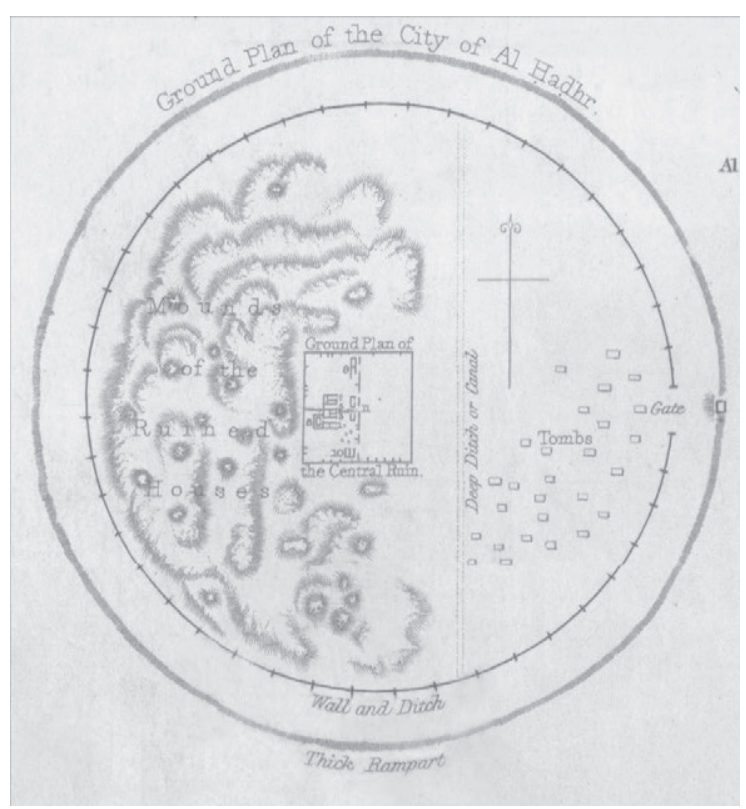

Fig. 1: General plan of Hatra (Ross 1839: pl. II).

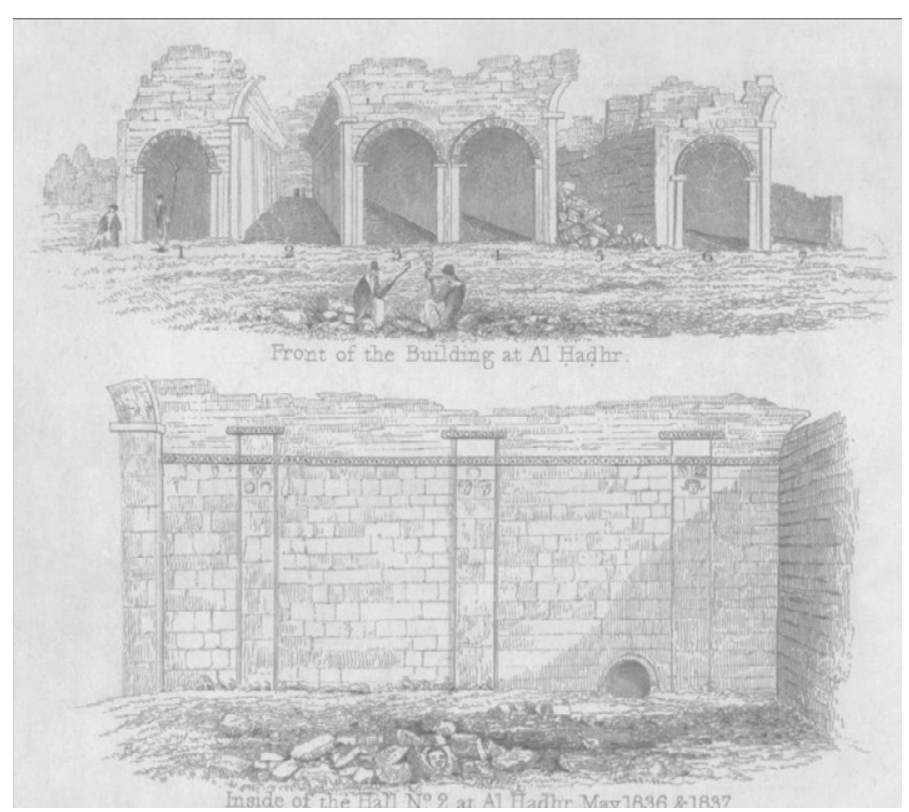

Fig. 2: Sketch of the Great Iwans and Twin Iwans and inner part of the Great South Iwan (Ross 1839: Pl. II).

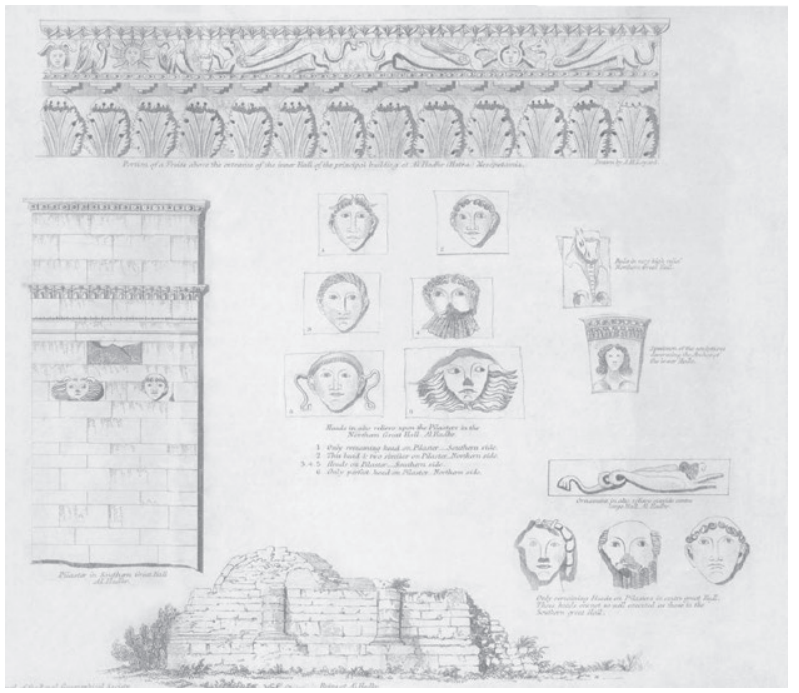

Fig. 3: Lintel decoration of the door between the Square Temple and the Great South Iwan, masques and decorated voussoirs of the Great Iwans. Façade one funerary building of the city (Ainsworth 1841: Pl. I, Layard's drawings).

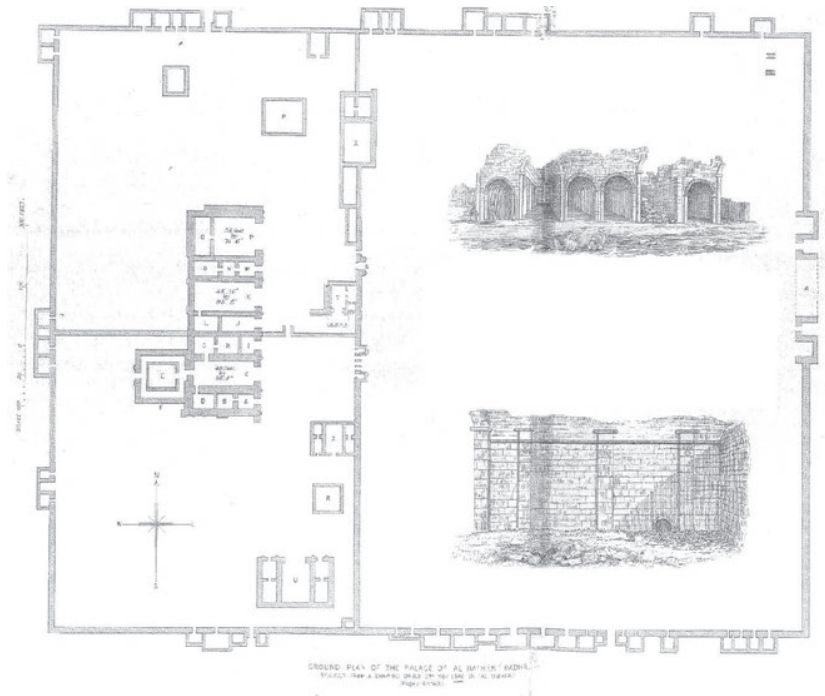

Fig. 4: General plan of the Temenos and sketch of the Great Iwans and Twin Iwans and inner part of the Great South Iwan drawn by Ross (Layard 1891). 


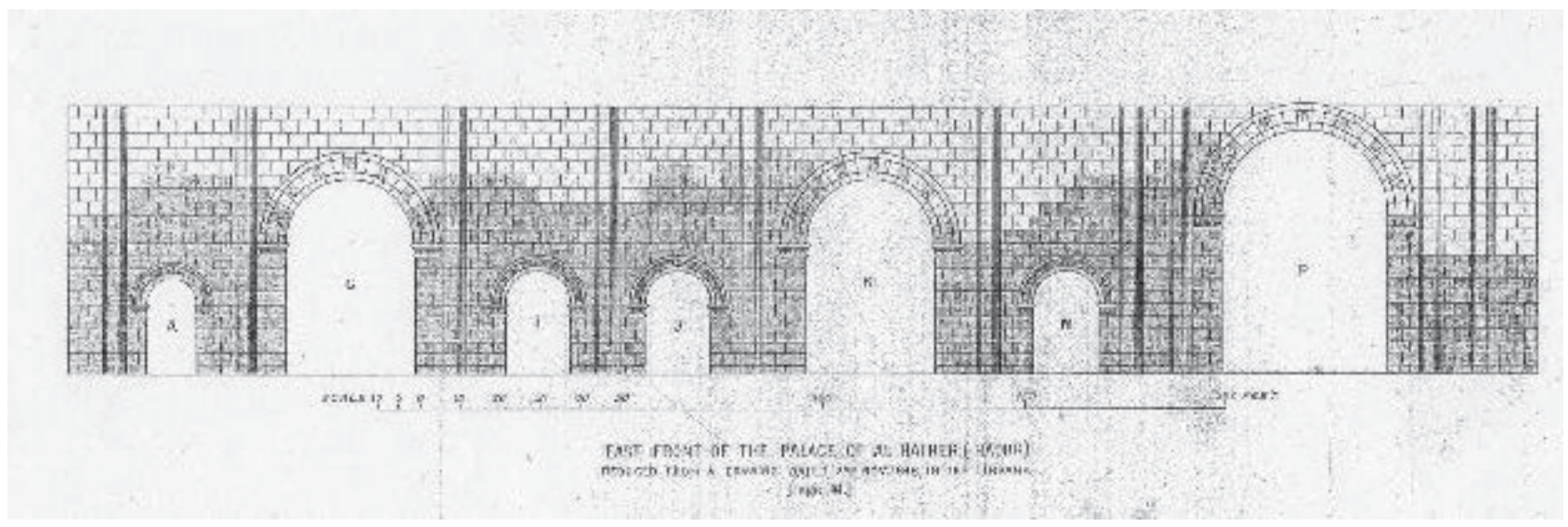

Fig. 5: Façade of the Great Iwans (Layard 1891).

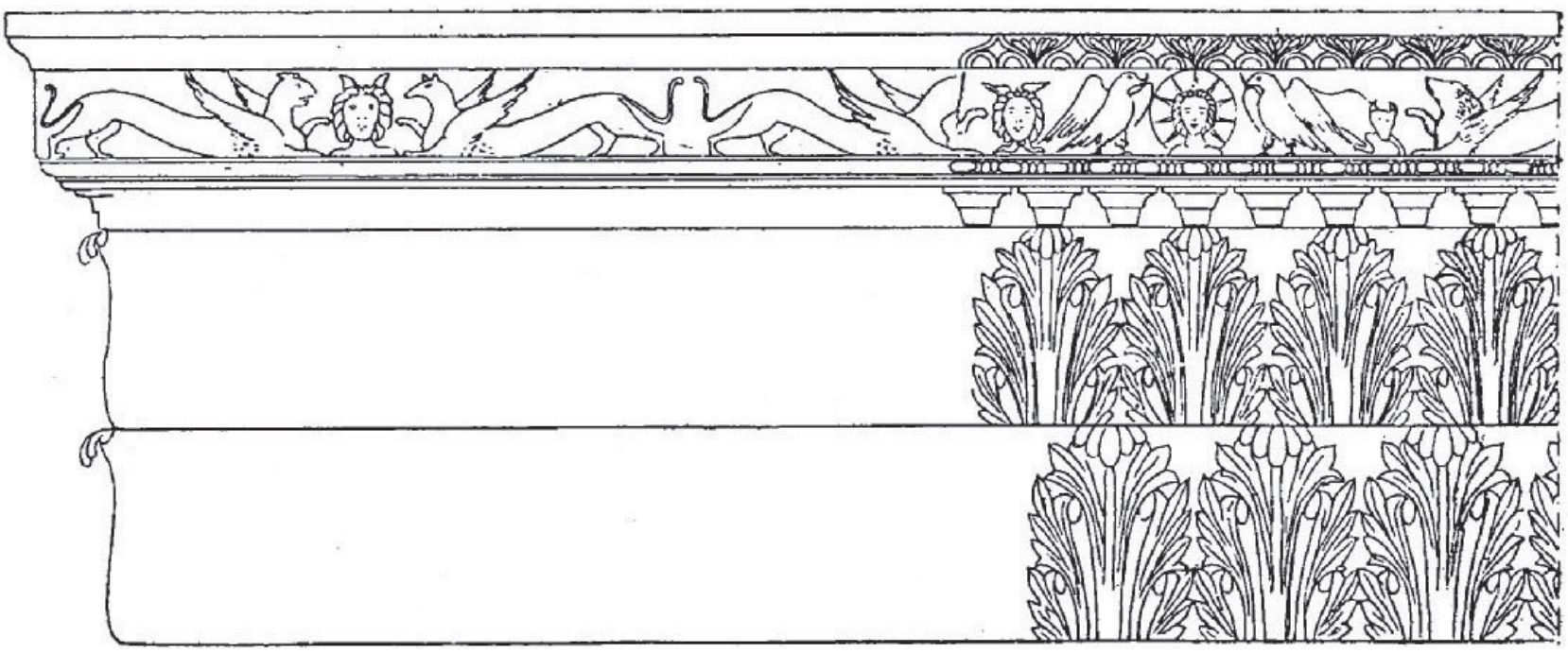

Fig. 6: Lintel decoration of the door between the Square Temple and the Great South Iwan (Jacquerel 1897: 350, fig. 7). 


\section{Monsicen le Minishe.}

Fous n'aves fait p'houment be n'aceorder en 1898 les menriers forsts neicessaires forr entuprentre les fonilles a Eochatal. Béfié, ch, au

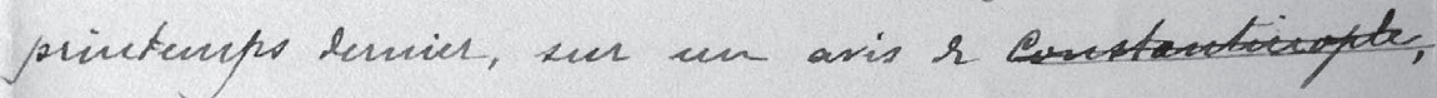
laubasade, jes hastair. pour Constantingfle. Le gouvemenent ture sélarait ne fas s'ofpaser aux fovilles ch attende sudenrent le consentement on proficietacie on terrain pour un biliver l'antoriration nécessace. I'espérais obteriir ec consentement eontre une indennité soismubre.

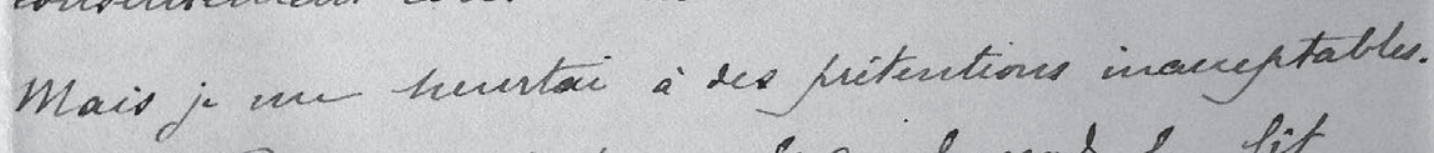
Fehim-bacha mulat que to airbassack be fit nommer Montessarif run sangiak iriéfen rant; if se erait entente rume pumeser, mais appuyei grun sipith \& quarante nille

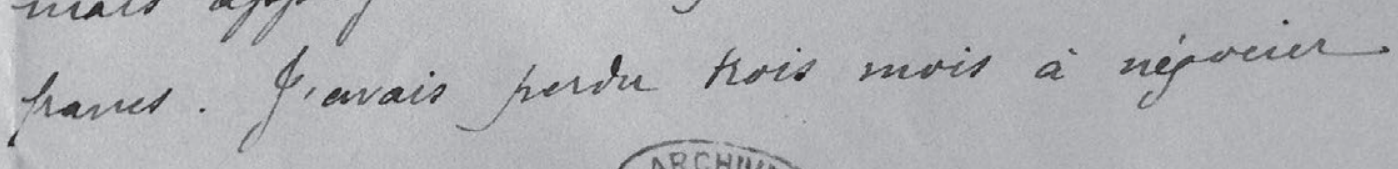
ARCHIVES

Fig. 7: First page of letter sent by Ch. Fossey to the French Ministry dated 30 April 1899 (Archives Nationales de France - Paris F17/2963). 


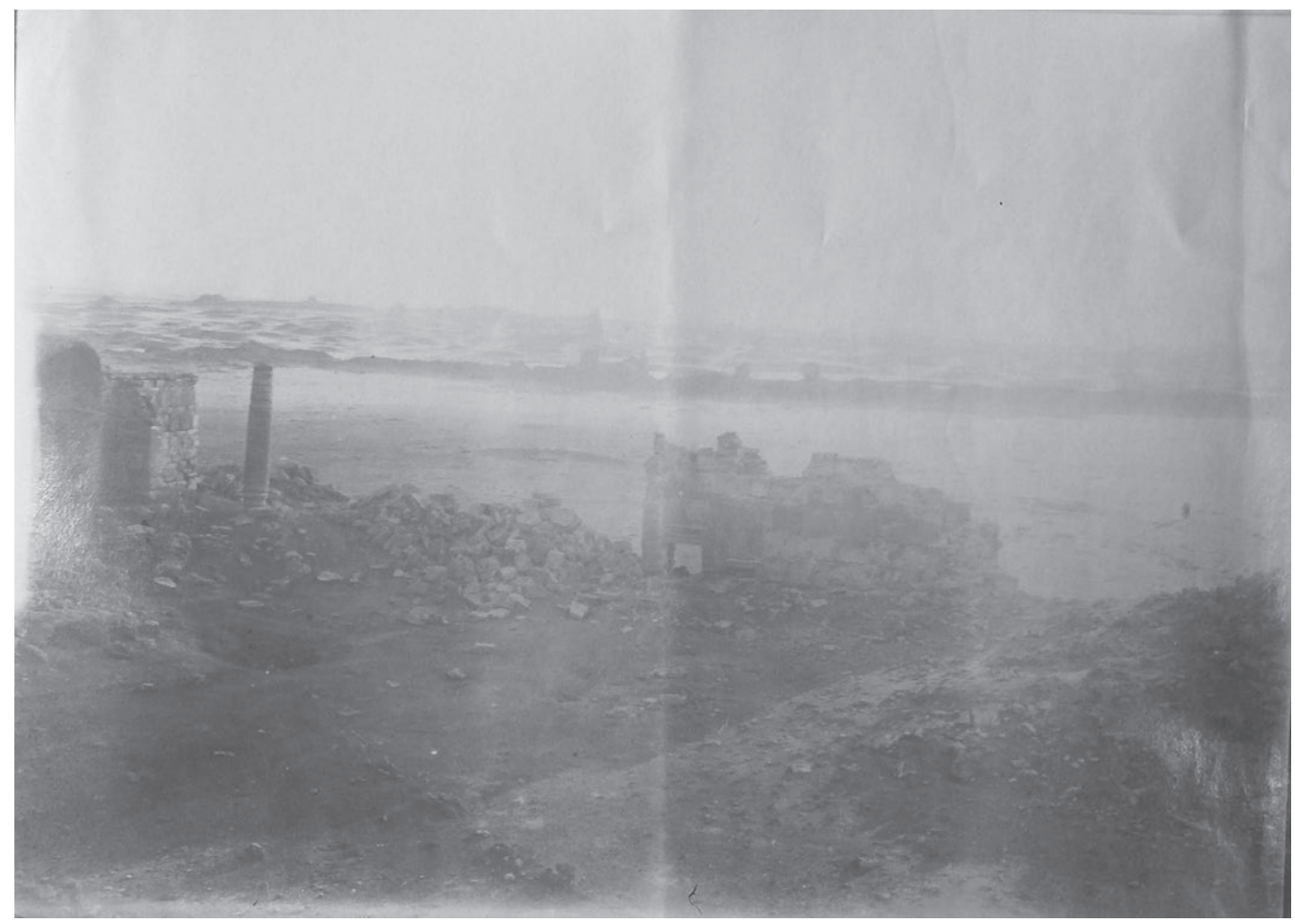

Fig. 8: General view of the Temenos area - Dossier Fossey, Photograph no. 1 (Archives Nationales de France - Paris F17/2963).

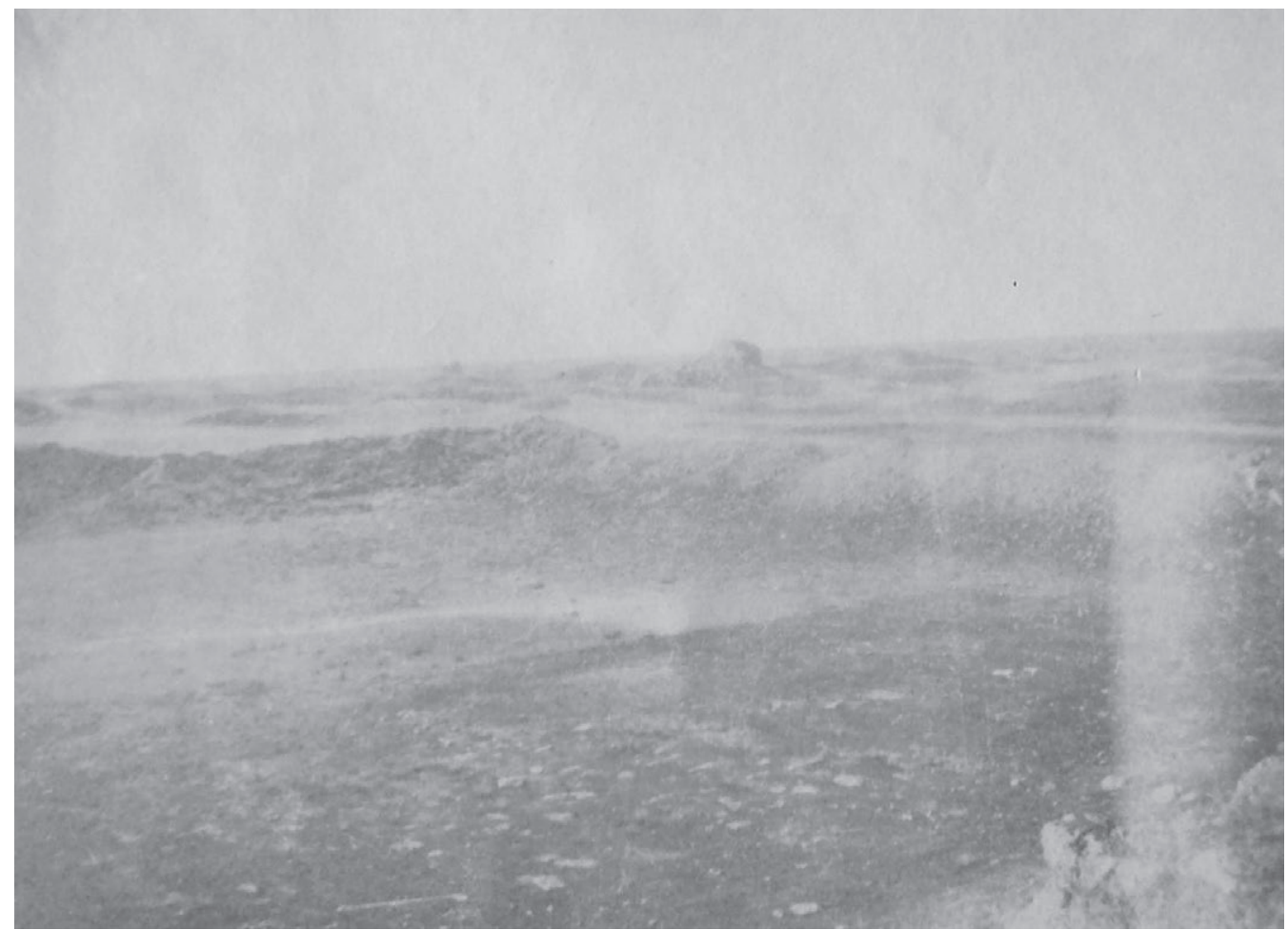

Fig. 9: General view of the Temenos area - Dossier Fossey, Photograph no. 2 (Archives Nationales de France - Paris F17/2963). 


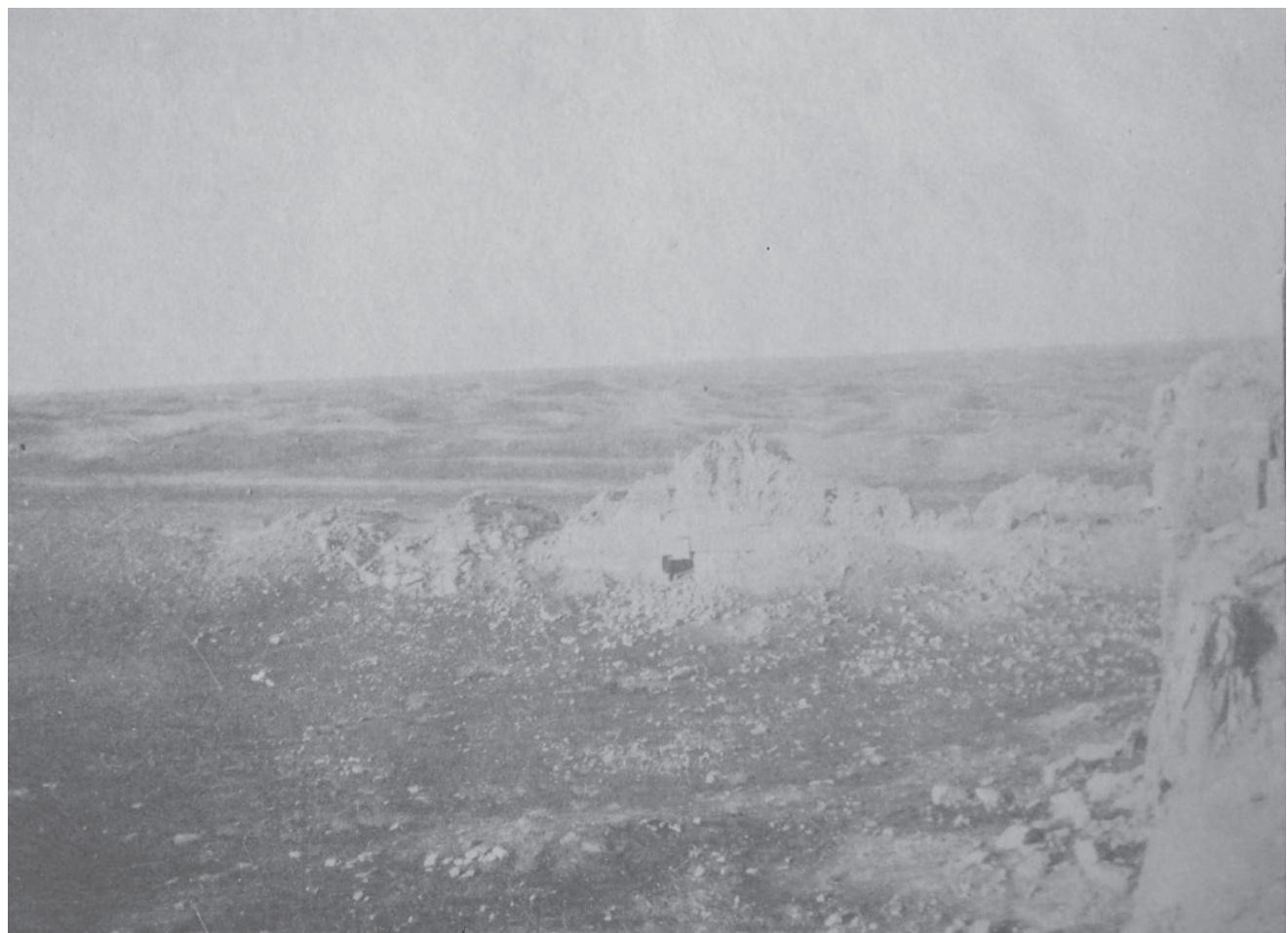

Fig. 10: General view of the Temenos area - Dossier Fossey, Photograph no. 3 (Archives Nationales de France - Paris F17/2963).

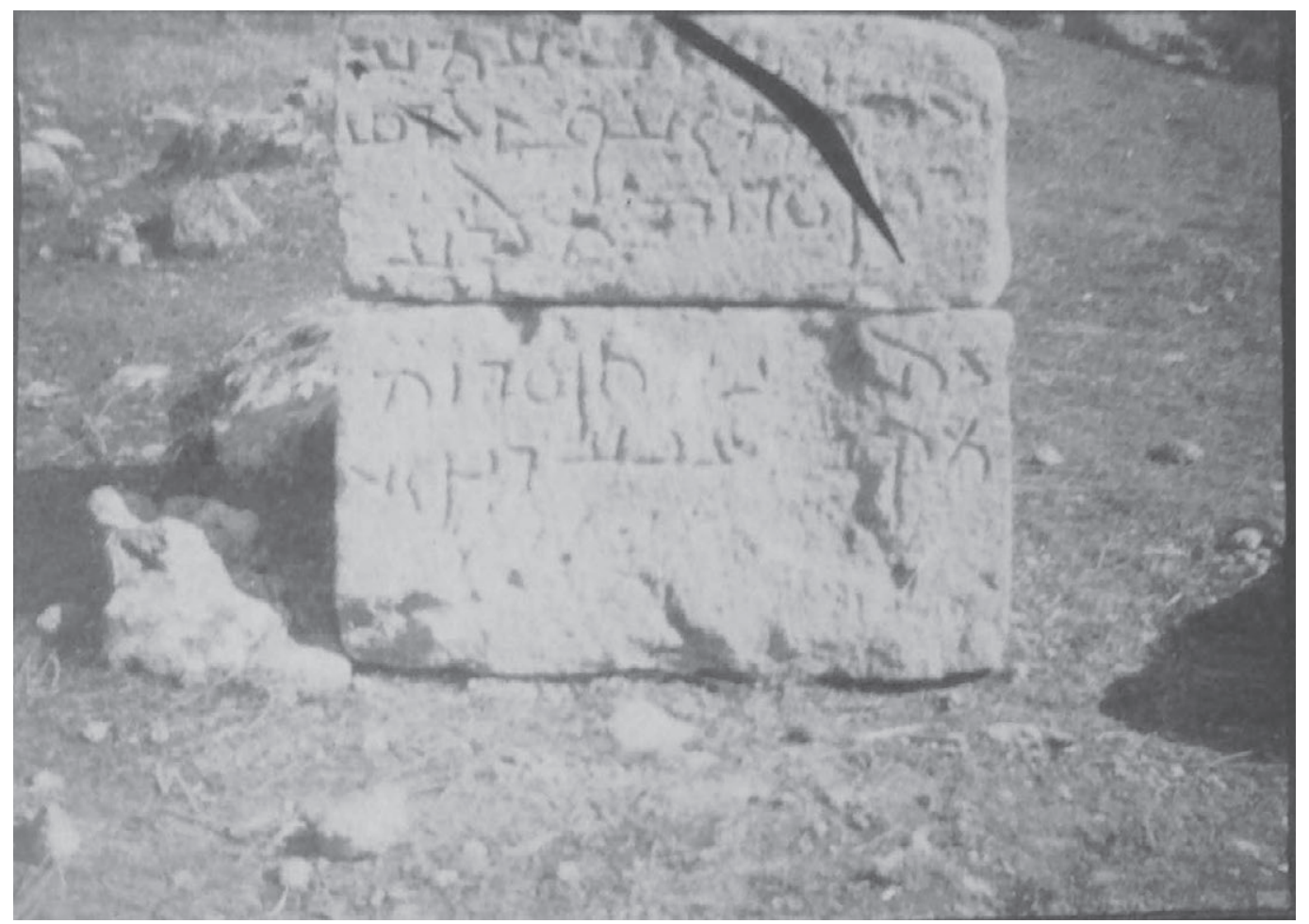

Fig. 11: Inscription H28 from Small Shrine 2 or the nearby west dwelling area - Dossier Fossey, Photograph no. 4 (Archives Nationales de France - Paris F17/2963). 


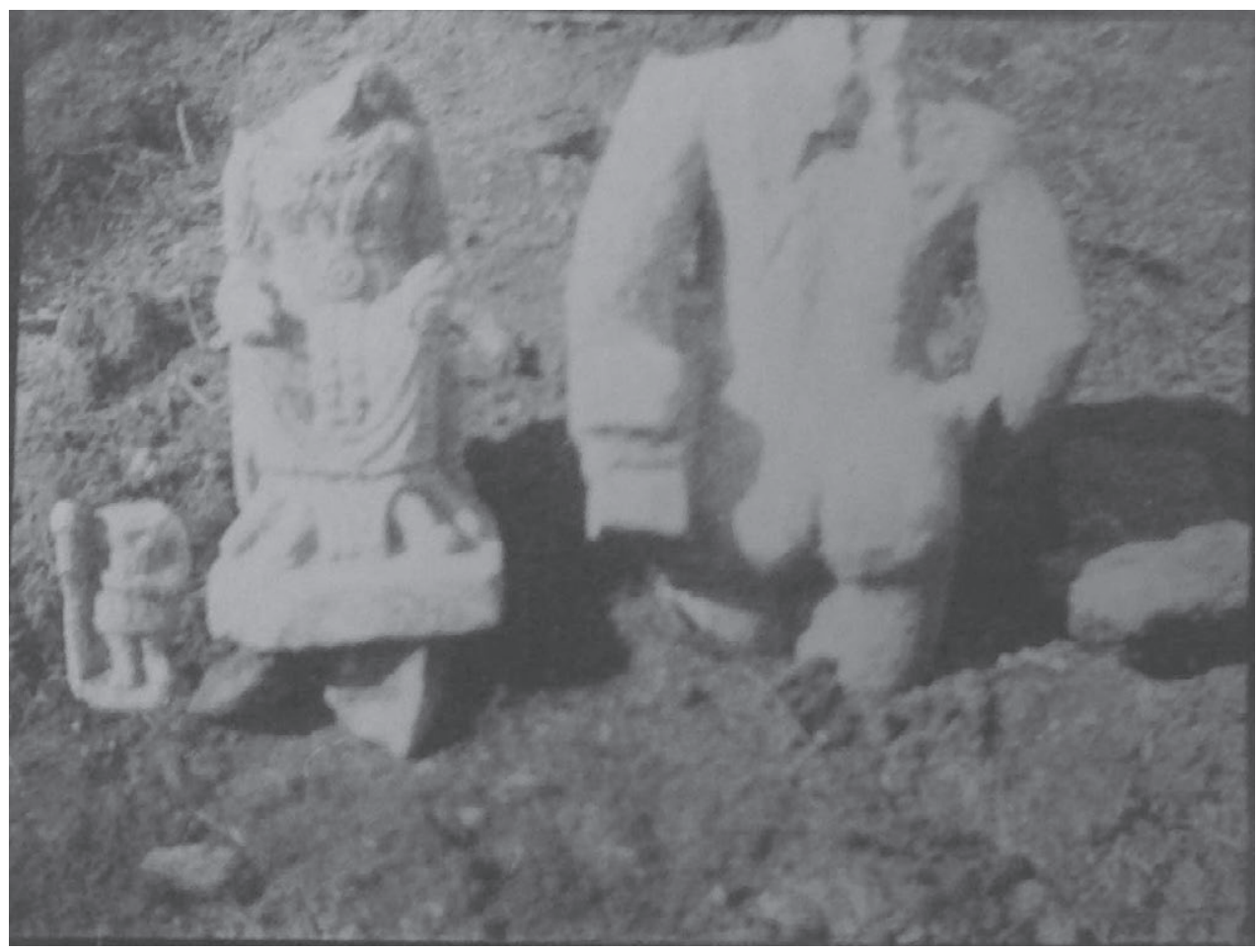

Fig. 12: Sculptures recovered by the French Expedition in the area of the Small Shrine 2 and the dwelling area nearby - Dossier Fossey, Photograph no. 5 (Archives Nationales de France - Paris F17/2963).

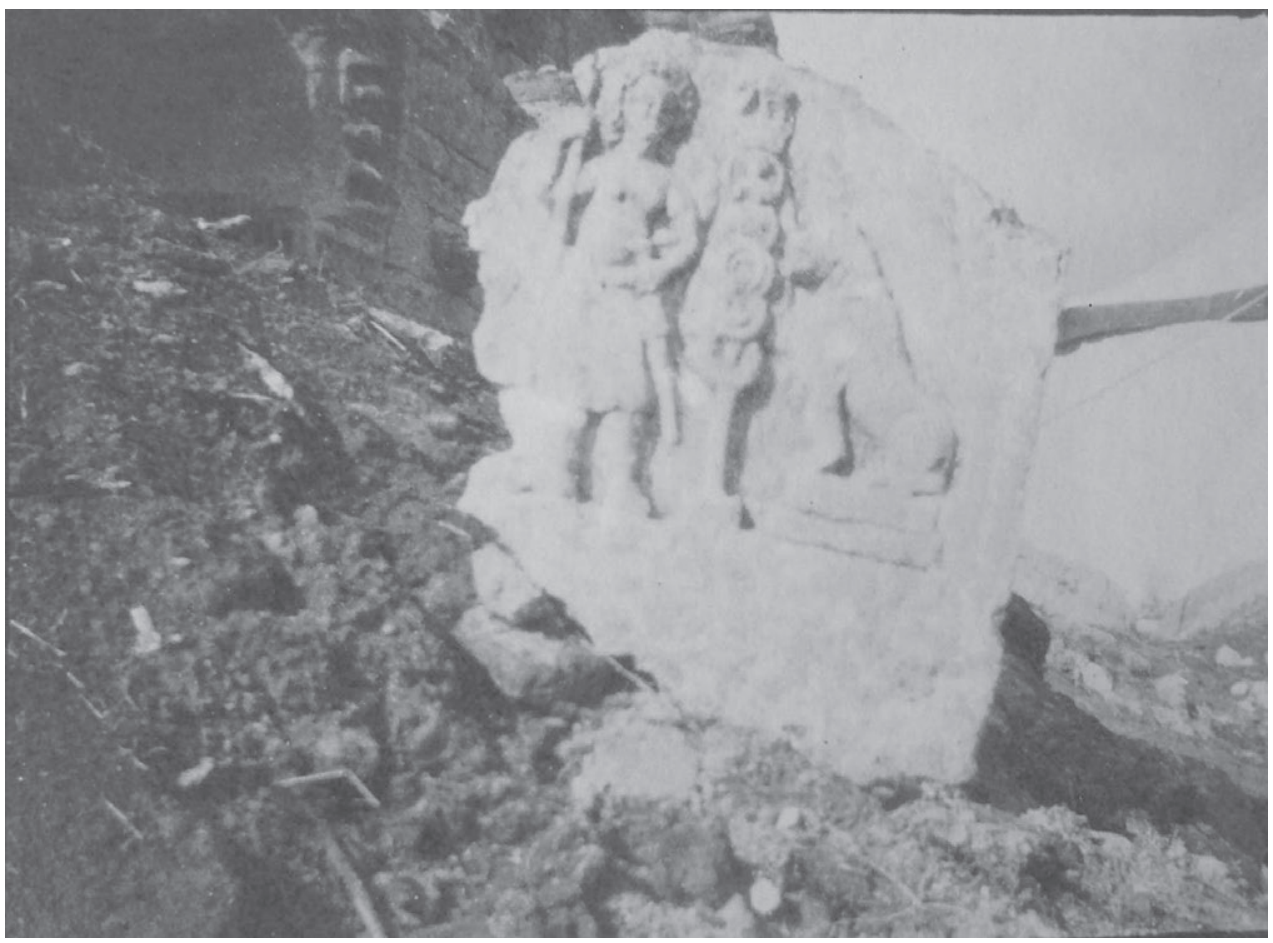

Fig. 13: Relief with a dog on a basement, attendant/god and standard (samya) - Dossier Fossey, Photograph no. 6 (Archives Nationales de France - Paris F17/2963). 


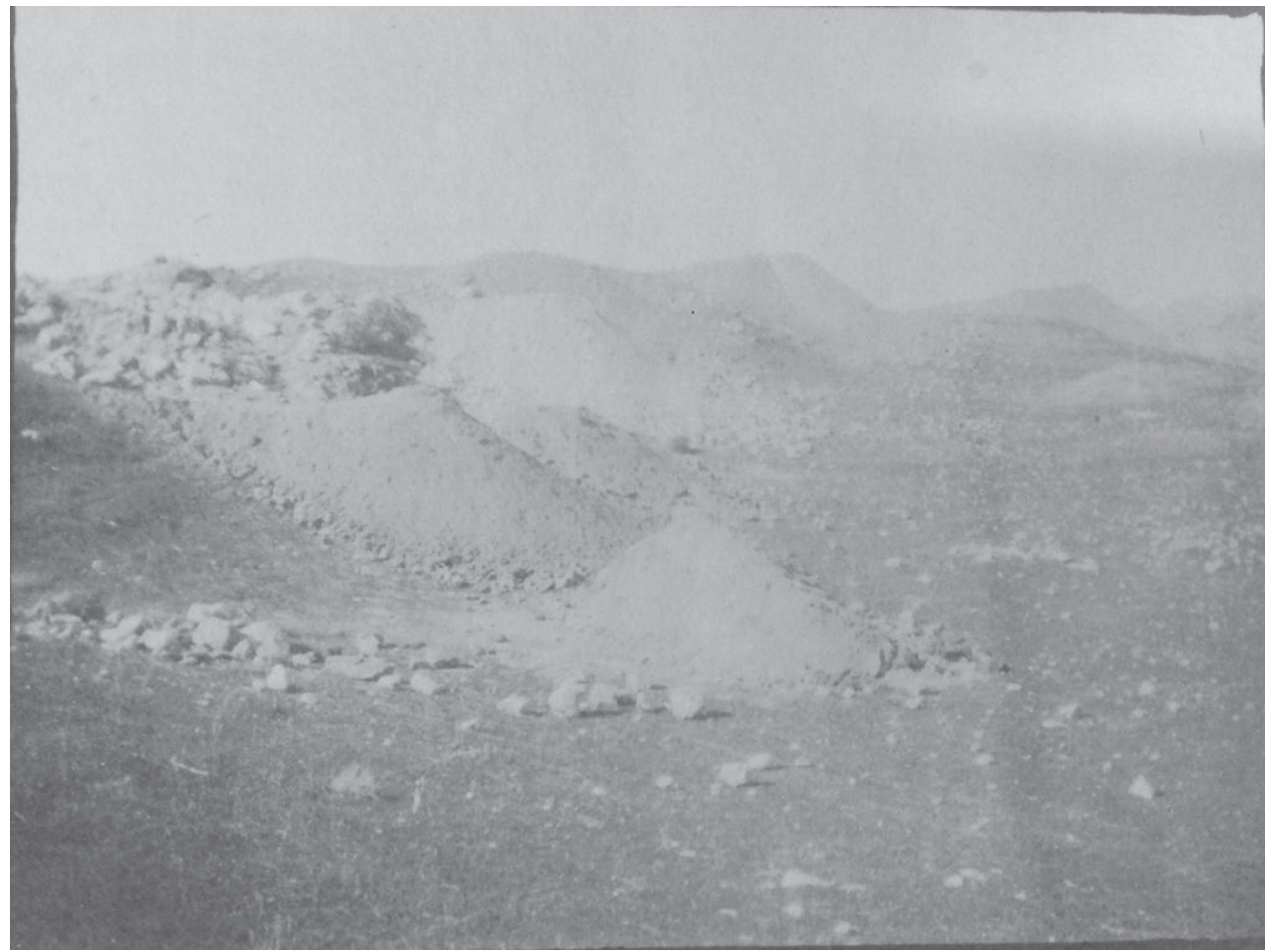

Fig. 14: Picture of the trench area (Small Shrine 2 and dwelling area nearby) - Dossier Fossey, Photograph no. 7 (Archives Nationales de France - Paris F17/2963).

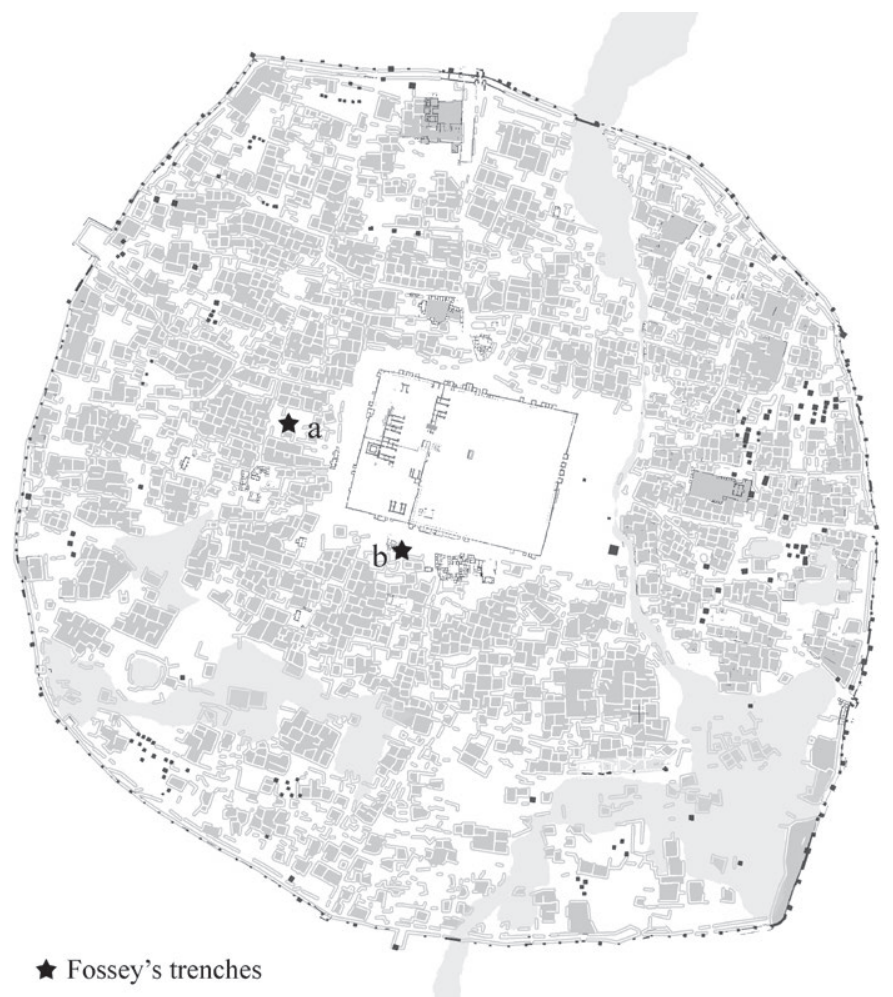

Fig. 15: Placement of Fossey's trenches (HatraGIS). 

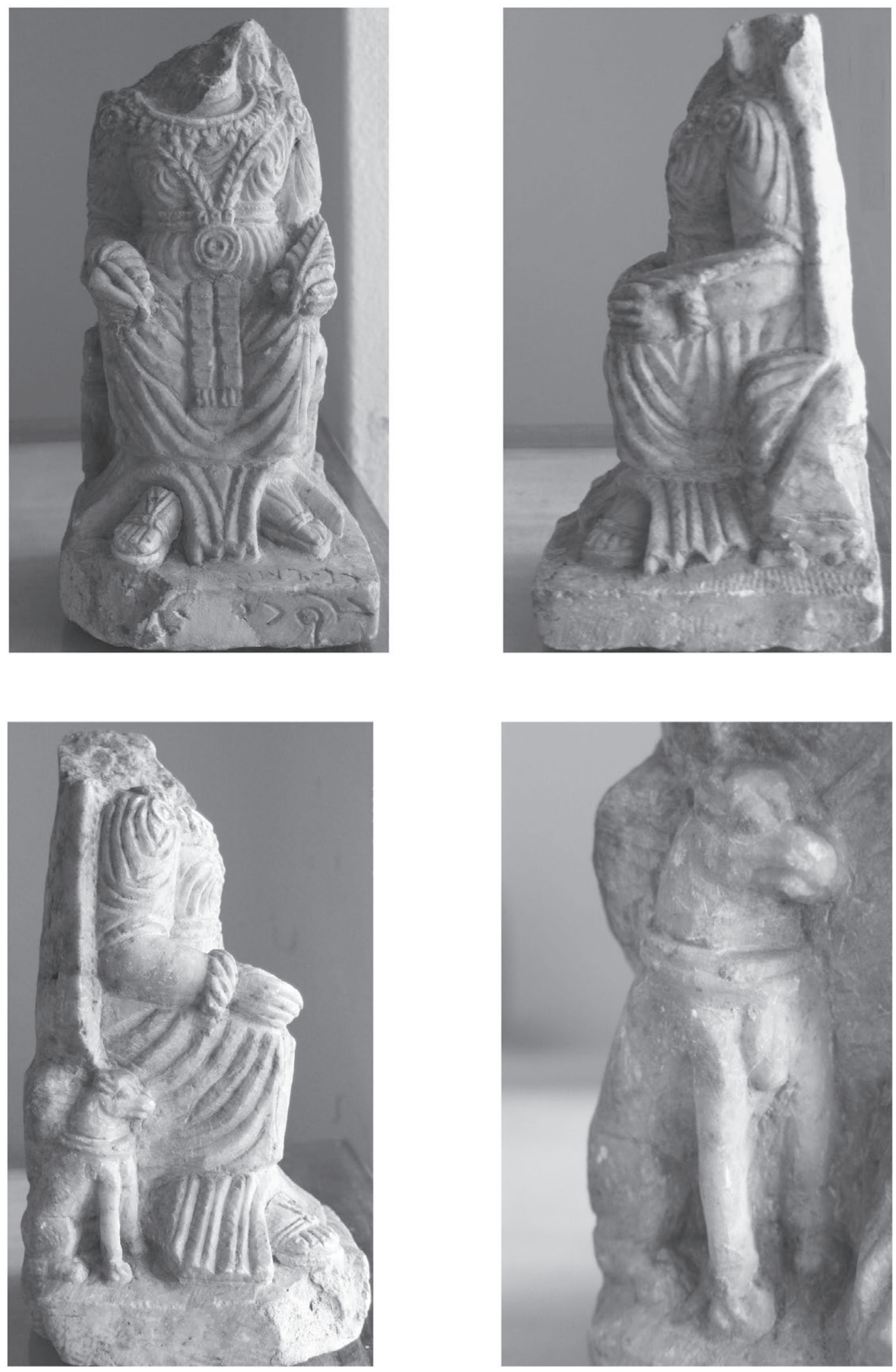

Fig. 16: Enthroned goddess from Small Shrine 2, Archaeological Museum of Istanbul, inv. no. 3831 (Dirven 2013b: 156, figs 1-4). 


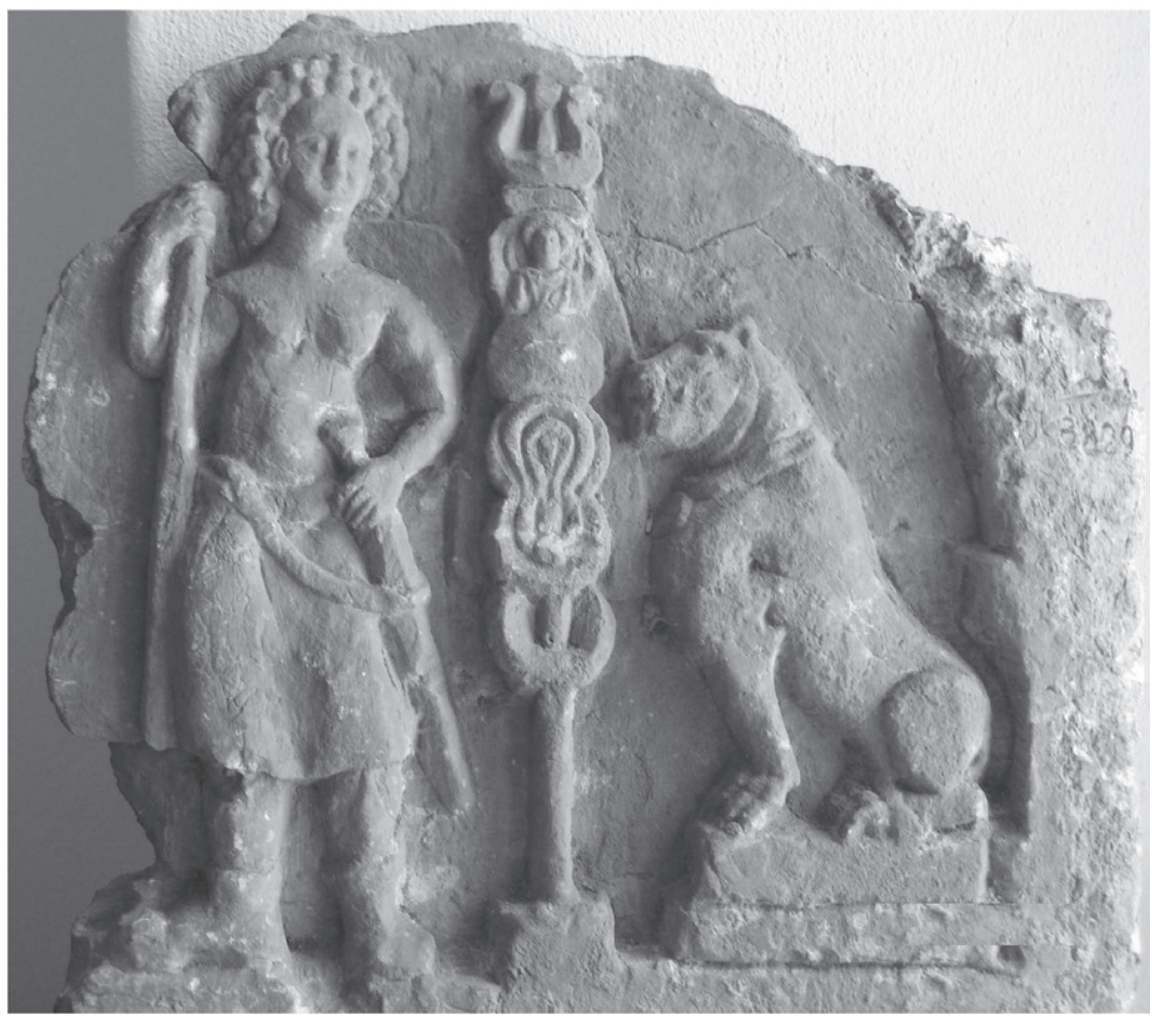

Fig. 17: Relief with a dog on a basement, attendant/god and standard (samya), Archaeological Museum of Istanbul, inv. no. 3829 (Dirven 2013b: 157, fig. 5).
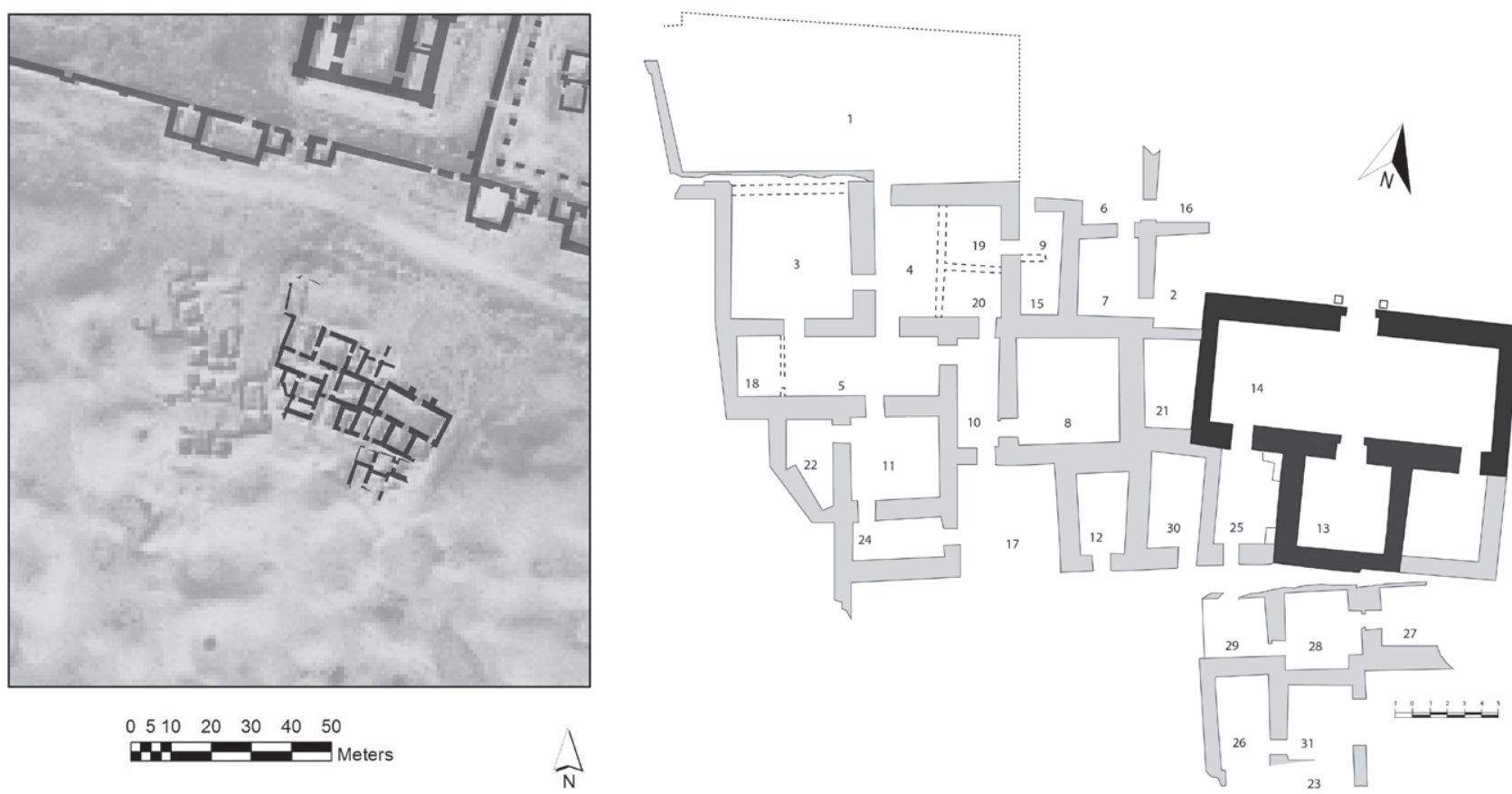

Fig. 18a-b: Location and general plan of the Small Shrine 2 and the dwelling area nearby (HatraGIS - E. Foietta from Safar, Mustafa 1974: 303). 


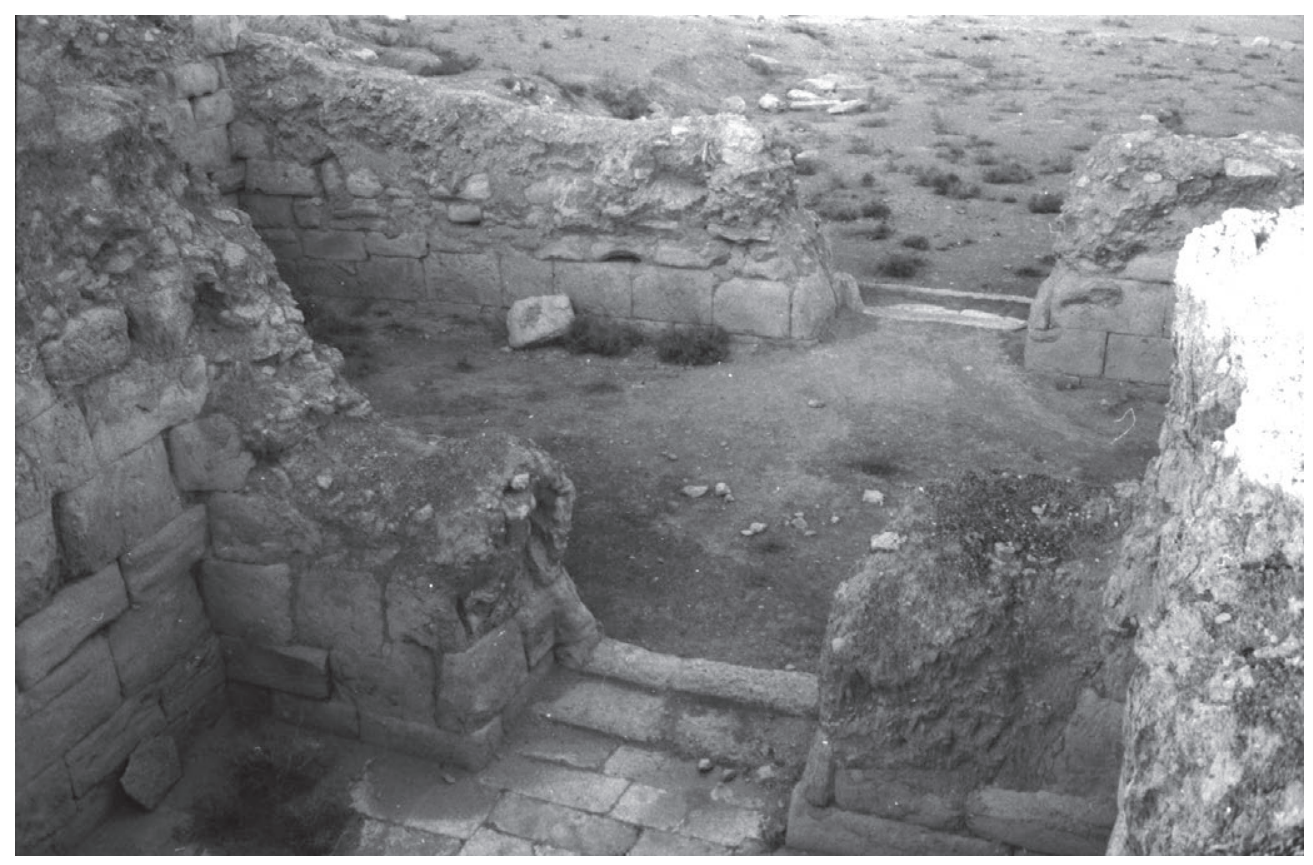

Fig. 19: Antecella of Small Shrine 2 from South (Archivio della Missione Archeologica Italiana a Hatra - Torino).

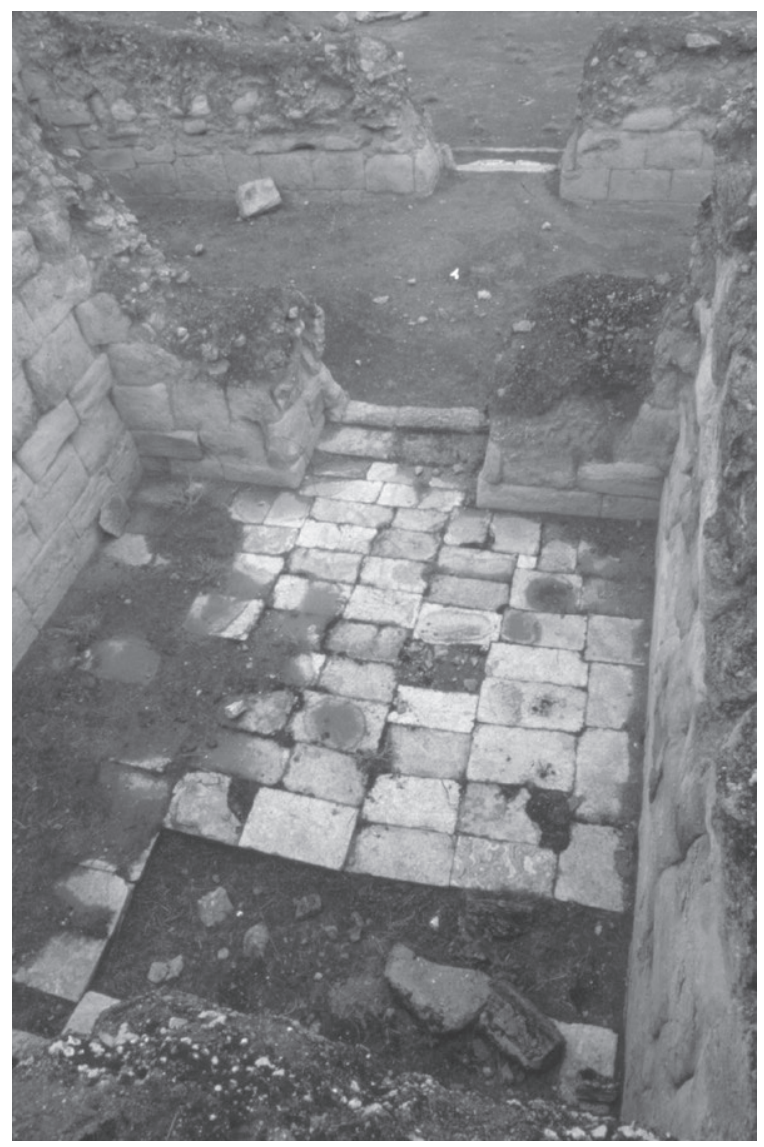

Fig. 20: Cella of Small Shrine 2 from South (Archivio della Missione Archeologica Italiana a Hatra - Torino). 


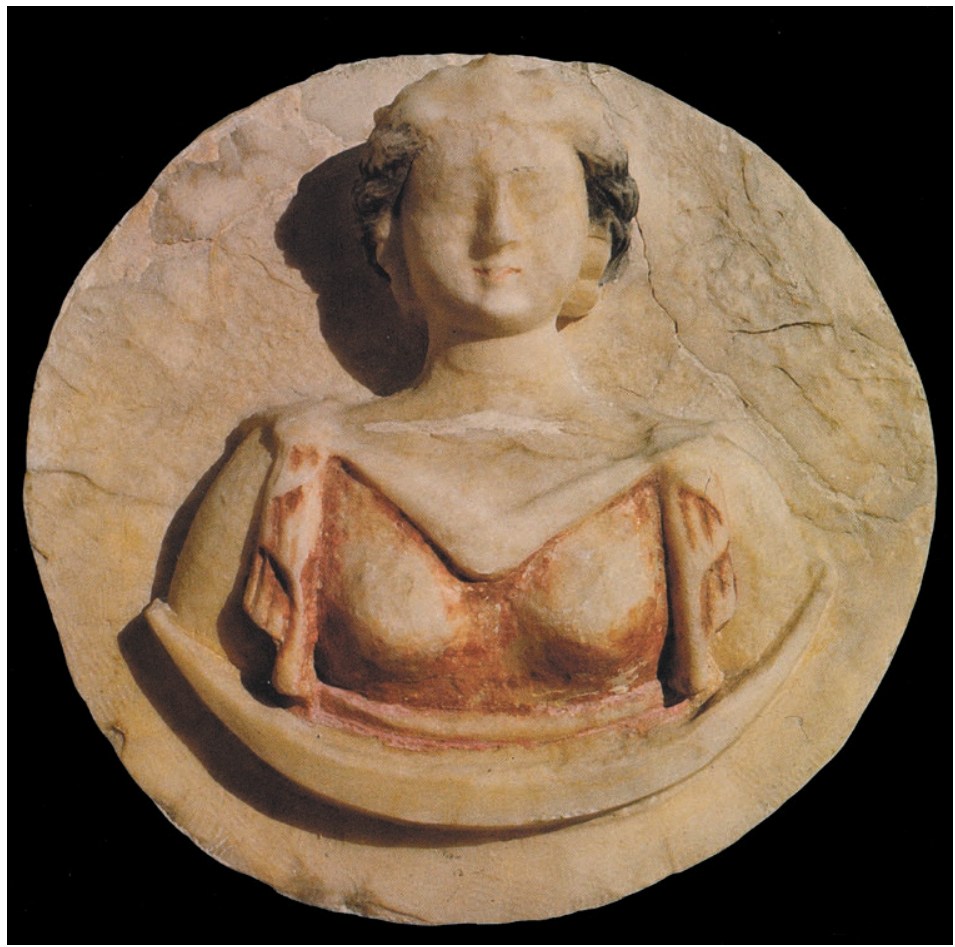

Fig. 21: Goddess on a round bas-relief resting on a carved crescent moon (Al-Salihi 1978: 27).

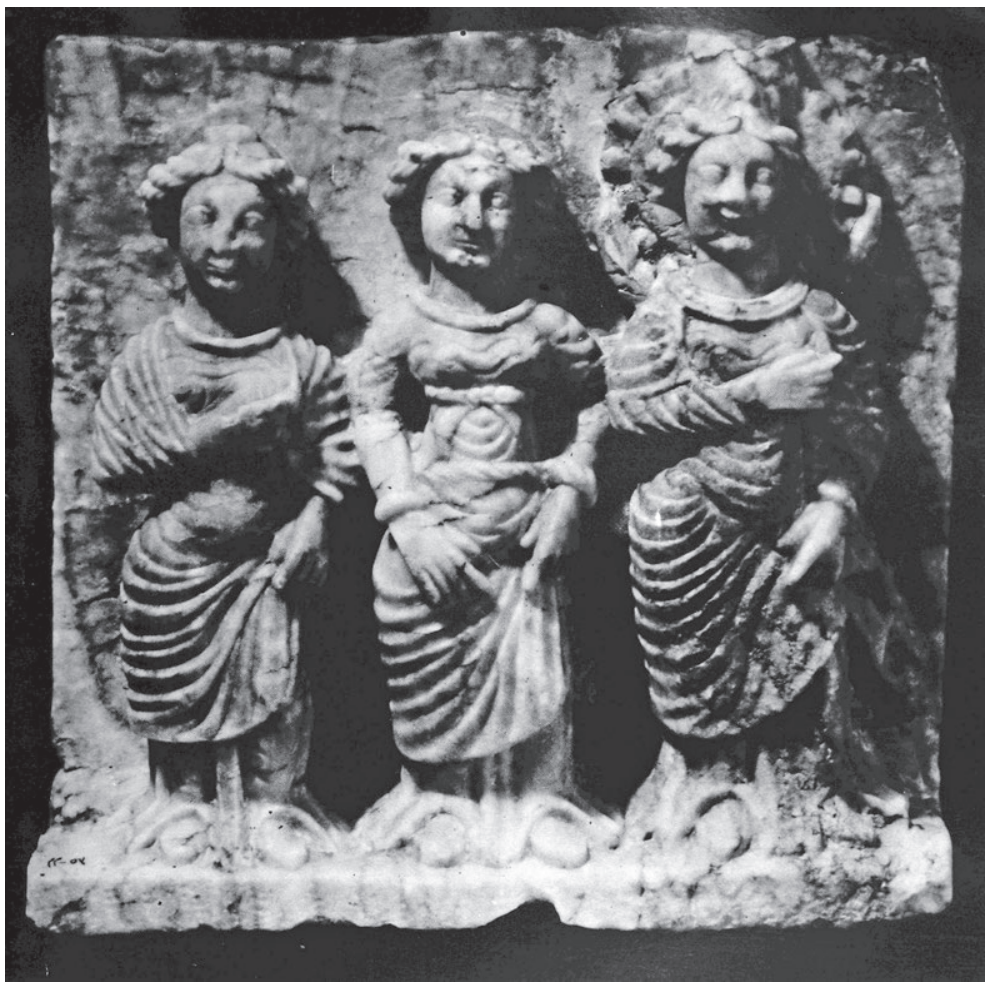

Fig. 23: Relief with three standing goddesses wearing long tunics (Safar, Mustafa 1974: no. 195).

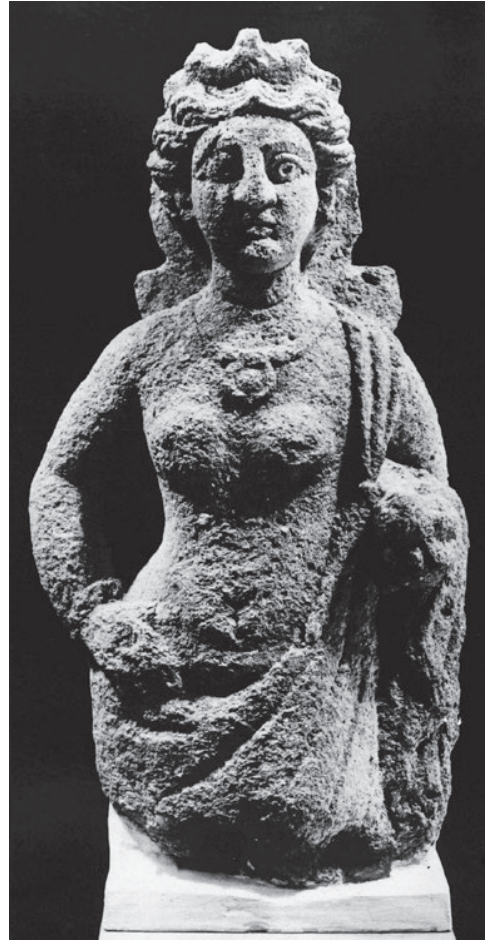

Fig. 21: Goddess on a round basrelief resting on a carved crescent moon (Al-Salihi 1978: 27).

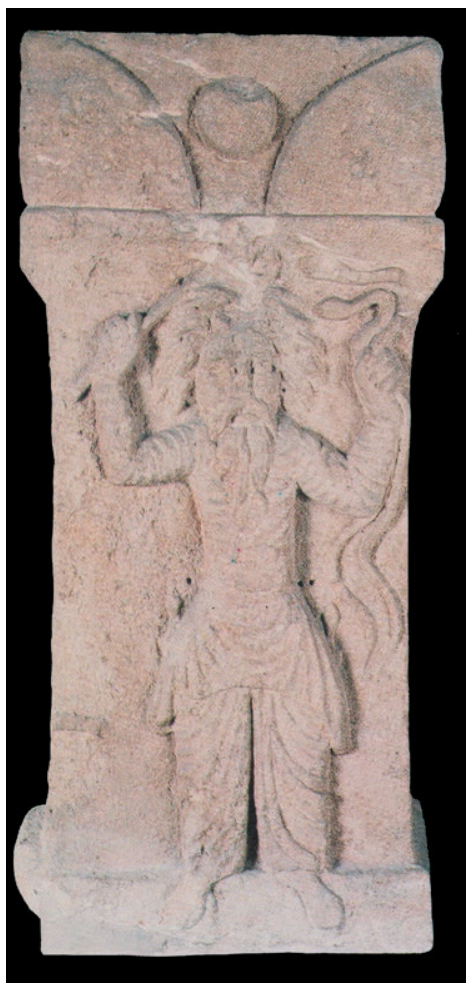

Fig. 24: Altar with a god carved on the main face (Al-Salihi 1978: 36). 